\title{
滋賀県耳鼻咽喉科の歴史
}

貝塚侊

\section{A Hisory of Otorhinolarngology in Shiga Prefecture}

\section{Kou Kaizuka}

Otorhinolaryngological special treatment in Shiga Prefecture began in 1912 almost same time at Otsu Red Cross Hospital by Dr. Kiyoshi Oosugi and Hikone Official Hospital by Dr. Shinichiro Miura. Auther described this 70 years medical history of otorhinolaryngology in Shiga Prefecture with 2 Parts.

lst Part: Topics of this history and changing otorhinolaryngological disease.

2nd Part: Chronological table of otorhinolaryngology in Shiga Prefecture and another related Japan, since 1868.

\section{は じめ に}

最も早く近代医学の発達した欧州でも耳科及び鼻咽喉科が医学の中で専門科として独立したのは 19世紀になってからである.

19世紀後半の明治になって我国にもヨーロッパの医学が続々と輸入され, 明治も終り頃になって 耳鼻咽喉科専門の診療がはじまった。

滋賀県に耳鼻咽喉科専門医が出来たのは，1912年即ち大正になってからの事である.

第一部にはそのトピックスと耳鼻科疾患の变遷を書き記した。それは人類と共に長い疾病の歴史 の中で医学と抗生物質などの進歩により耳鼻科領域でもこて数十年ほど疾病の变化した時代は無い からである.

第二部には年表としてその年に起ったてとがら总記し，一方に滋賀県と関係の深い京都が主にな っているわが国の耳鼻咽喉科の歷史を記した。それは滋賀県の耳鼻咽喉科の学会が今も京滋合同で 行われている様に, 古代, 中世営通じて日本の最大都市であった京都觉除いては之を語る事が出来 ないからである．現在も滋贺県に於て耳鼻咽喉科の診療を行っている医師の大部分が京都大学，京 都府立医科大学, 又はその関連大学で医学を学んだものが大部分である.

目次
第一部
1）古代の医療と信仰
3）駆梅にはじまった病院
2) 近江の薬草
4）大津に生れた浅井健吉
5）滋賀の二大事件

滋賀医科大学講師（非常勤） 
6）専門医のはぼまりと細田忠四郎

7）滋賀県耳鼻咽喉科医会の誕生

8）ヂフテリア

9）結核と耳鼻咽喉科

10）造鼻術と顔面形成

11）湖国之耳の感染症
12）手術方法の変遷

13）学校保険

14）西川吉之助之草津龍話学校

15）医師の教育と滋賀医科大学の開講

第 2 部 年 表

\section{1）古代の医療と信仰（耳だれ不動）}

7 世紀, 推古帝の頃, 近江滋賀郡小野の出身 である小野妹子は遣唐使として大陸にわたり中 国の医学を我国に伝えた。

この随とそれにつづいた唐の制度にならつ て, 我国最古の医事規定である医疾令が大宝元 年 (701) に出来上った.

之には医学の分科として体療 (内科) 少小 (小 児科) 創腫（外科, 皮膚科）耳目口柬（耳鼻咽 喉科，眼科，歯科）の四分科があった事が記さ れている.

室町時代以後には近江より坂浄快, その子浄 秀などの坂本一門, 板坂宗頓, 同宗徳などの板 坂一門の如き名医が出ている. 併し多くは草深 い近江の地を離れ，京都に出て成功したもので ある.

この傾向は江戸に入ってますます拍車を加え 近江出身の著名な医家は相当の数にの心゙ってい る. 勿論京に出て成功した後近江に帰って故山 に骨を埋めた名医もあったが，てれは例外であ った.

琵琶湖の水が集って瀬田川となり, 宇治に行 く途中は最も流れが紐く往時, 鹿がとびこえた と云われる所がある.とこにかけられた鹿跳橋 を渡って左へ信楽川に沿った渓谷を約 $3 \mathrm{~K}$ 行く と左手に巨大な岩山が見える。

川にかかった不動橋を渡ってしばらくこの山 坂をのぼると眼前に切り立った屏風の様な大岩 壁があり，ここに巨大な 4 つの石仏が彫まれて いる.

中央最大の阿弥陀仏の右の耳のあたりより岩 からにじみ出た水がしたたり, 岩の色が写真の 様に変化している．之が有名な「耳だれ不動」

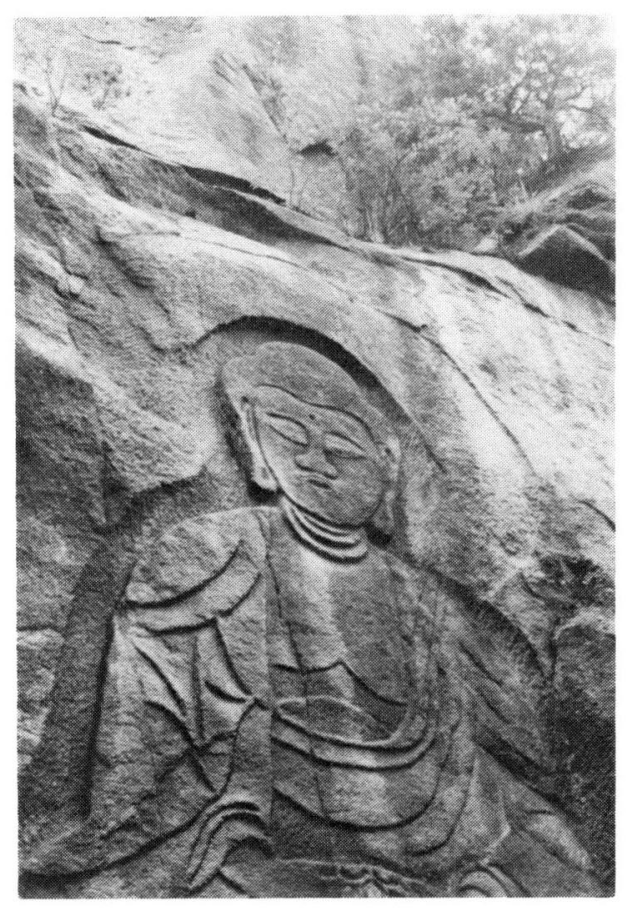

大津市富川の「みみだれ不動」

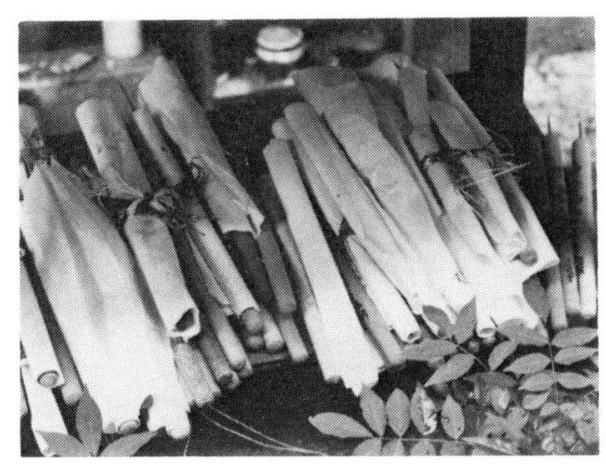

奉納された錐

で古くより耳の病気に悩む人々は, はるばるこ の磨崖仏に参拝し，そなえてある錐を持ちかえ 
り耳漏の回復を祈った.

ここは霊亀元年 (715年) 義淵の開基したもの と云われ，岩屋山明王院と号した寺院の跡であ
る.今もなお患者の名を記した記帳があり, 病 気の治療したお礼に持参した新らしい錐が高く 積まれている。

\section{2) 近江の薬草}

織田信長は宣教師のすすめに従って伊吹山に 西洋の薬草を多く移植し，薬園を開いたと伝え られ，今も伊吹山は薬草の宝庫である.

特に负に使われる伊吹もぐさは江戸以後に有 名になっている，又湖東の日野，甲賀の売薬は 近江売薬として富山，大和と並んで全国に名を 馳せていた。

耳鼻咽喉科疾患中最も多い耳疾には古くより ユキノシタ（虎血薬）が民間薬として用いられ て来た．ての草にはミミダレグサと云う別名が 残っている椂に，痛んだり，膿が出ると云う耳 疾にこの草を揉んで出た汁を耳にたらし込まれ たものである.
往時ほどでないけれど，最近でも滋賀県では 田舎から来た中耳炎の子供に耳に何かが入って いるので取出して見るとてのュキノシタであっ たりする。

耳漏のある子は「みみご」と云われ，耳漏の あるのは健康な証拠であり, 耳漏が急に止まれ ばかえって良くないと云う老婦人の声を聞いた 事がある。之は中耳炎より頭蓋腔内合併症を起 した時には急に耳漏が止まる事を知って云い伝 えられたのであろう。

又十薬（十種の病に効く）と云われるドクダ ミは化膿性の腫れものに用いて, 膿を吸い出し たり，煎じて飲まれたりした。

\section{3）駆梅にはじまった病院}

西洋の病院のはじまりは中世のエルサレムへ の巡礼の宿からであったのに対して，京都，大 津などに明治初期作られた病院のはじまりはそ の治療の主目的は駆梅のためであった。

滋賀医科大学が出来るまで滋賀県の最終病院 であった大津赤十字病院の前身は明治 9 年県に よって作られた駆梅院であり，翌年より一般患

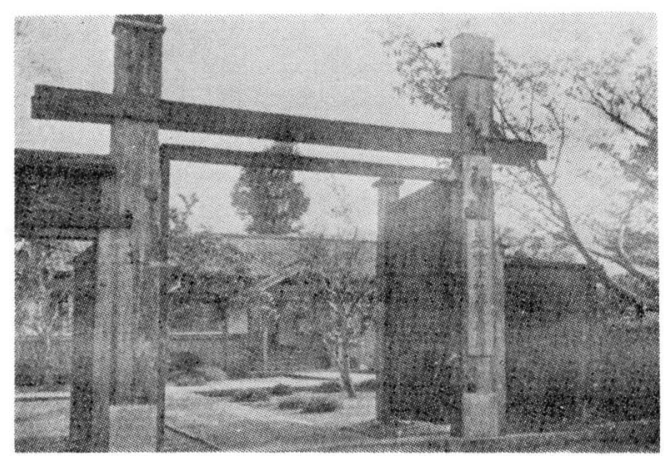

日赤滋賀支部病院 明治 9 年 7 月に大津湊町に創立 され,後松本村(現京町 4 丁目)に移転された. 正則医学 教場を設けて生徒 60 名を募集した. 写真集. 大津より
者の診療をはじめた。

明治 5 年に開かれ京都府立医科大学の前身で ある京都粟田口療病院もその設立主目的は種痘 と駆梅であった．明治 7 年の粟田口療院の記録 によれば総計1191名の外来患者のうち消化器病 251 名, 外科的病 162 名に次で多いものは皮䖉 病, 梅毒の138名であった. 眼病は123名と次に 多く, 耳病は37名であったと記されている.

この療病院は明治13年京都府医学校となり, ここの教諭の江馬竜太郎は明治 30 年より大正 3 年まで皮膚科, 梅毒科, 耳鼻咽喉科部長となっ ていて耳鼻咽喉科は独立したものでなかった。

コロンブスが新大陸より欧州に持ち来したと 云われる梅毒は，20年後に早くも我国に上陸し て江戸時代には上下貴賤を問わず蔓延してい た. 特に京都，大阪，江戸などの大都市とか交 通の多い宿場町大津などでは患者が多く，大阪 で開業していた杉田玄白は毎年見る千人の患者 のうち 7 ～800 人は梅毒患者であったとその著 
書「形影夜話」の中で述へ，嘆いている。

第三期の梅毒となれば鼻中隔穿孔による鞍鼻 となるばかりでなく, 鼻の落ちた患者もあった。 当時大津の山ぞい，現在の逢坂小学校の南にあ る丸山の下に県立避病院が建てられていた。之 は明治10年発生したコレラの隔離にはじまった もので，其後腸チフス，天然病患者なども多く 送られ，現在国道 1 号線となっている旧東海道 線下の地下道よりは殹の列が続いたと云われ る.

ここには大津遊廓などから送られた梅毒患者 の別棟があり，鼻のくずれた醜い患者の姿も見 られたので，そのためての周辺は人々は一層恐 れて近づかなかった所であると伝えられてい る.

当時の梅毒療法は副作用が強くて投薬には余 程の注意を要した伊勢白粉と称した水銀剂が唯 一のものであった。明治 42 年泰佐八郎がェール
リッヒと共に発見したサルバルサン (606号) は 装年我国に輸入され，当時の医師はその著效に 驚いた。併しこのサルバルサンの注射は大正の はじめ, 点耳, 点眼薬の薬価が約20銭であった のに対して15円もする高価なものであった。

梅毒忠鼻を犯すばかりでなく,内耳をも犯し, 又先天性梅毒児の $1 / 3$ は龍者であった。

戦前までは患者を見れば先づ梅毒を疑えとは 医師の常識であって，第二期梅毒の症状である 咽頭の乳白斑は耳鼻科医がよく発見したもので ある。

現在でも滋賀県赤十字血液センターで年間 6 万人以上行われている採血の中には $1 \%$ 以上の ワッセルマン反応陽性者がある。この值は全国 平均の $0.5 \%$ 余りより多い数值である. 耳鼻科 では現在あきらかな梅毒症状を発見することは 殆んどないけれども，今も決して忘れてはなら ない病気である。

\section{4）大津に生れた浅井健吉}

我国の耳鼻咽喉科の専門診療は明治23年東京 の日本赤十字病院で賀古鶴所の行ったものが噮 矢である.

大阪における草分けはドイッで耳鼻咽喉科を 学んだ後, 明治 28 年緒方病院分院で診療をはじ め後に堀内病院を開設した堀内謙吉ドクトルで ある.

京都では明治35年京都医科大学講師となって 耳鼻咽喉科の診療を開始した浅井健吉がはじま りである.

浅井健吉は明治 5 年, 当滋賀県大津市の洋法外 科医，浅井東太郎の長男として生れた。第三高 等学校の前身である, 当時大阪城の近くにあっ た大学予備門に入学, 東京大学京卒業, 岡田和 一郎が明治32年新たに開いた耳鼻咽喉科教室に 久保猪之吉と共に入門した。

我国にはじめて生れたばかりの耳鼻咽喉科に 対して, 門外漢が耳鼻科って一体どんな科です かと彼に尋ねた時は「耳鼻科と云うのは外科の ヤッがやっていた隠床医学と, 主として内科で
手がけていた呼吸道の咽喉と鼻を取り上げて専 門にやろうと生れたもので，内科でも外科でも やれない新しい特殊な医学体系京打ち建ててや ろうと云うものじゃ」と答えた。

京都大学赴任後その耳鼻咽喉科創設に骨を折 り大正 2 年と大正 5 年に二回にわたり宿題報告 を行っている.

外科学助教授として洋行中の和辻春次がその 目的变变更して, ウィーンの Hajek の下で耳 鼻科を研究して帰朝し, 明治38年京都大学初代 耳鼻咽喉科教授となった。しばらくして講師の 彼は京都在去りバーゼルの Siebenmann 教授 の下で先天梅毒の聴器病理の研究を行い, 帰朝 後は大阪の回生病院に勤務の後, 浅井病院を建 てた。

晚年まで本をよく読み，学会では日本の耳鼻 咽喉科のパイオニアの一人として一言居士で押 し通した。

彼には香道の免許皆伝の余技があり，炤和 20 年 5 月, 73 才の最後まで蜜蜂の嗅覚器の組織標 
本を作らせてコッコッと顕微鏡を覗いていた. その多くの蔵書は現在大阪の军田病院に残され ている. 現在大津の京町 1 丁目に彼の生家が残
っていて，外科医となった長男東一博士がこて に自適生活を送り，本年 9 月77才の生涯を閉じ た.

\section{5）滋賀の二大事件}

明治時代，滋賀には二つの大きな事件があっ た.

その一つは明治 24 年 5 月 11 日ロシア国の皇太 子が琵琶湖見物の帰途, 大津の市内で沿道警備 の津田三蔵巡査に切りつけられた，いわゆる大 津事件である.

この時京都府医学校長兼院長, 猪子止才之助 はただちに滋賀県庁にかけつけ応急手当を行っ ている. 又同年10月28日起った濃尾大地震にも 猪子校長は医員や生徒を引きつれ大垣に出張 し, 負傷者の治療に当った。彼は耳鼻咽喉科の 歴史の上でも，明治 21 年 4 月，京都療病院でわ が国はじめての喉頭全剔出術を行っており，東 京で佐藤三吉が同手術を行ったのはての年の 11 月のととである.

この関西外科の重鎮であった猪子校長は， ヨ 一ロッパに自費留学し，明治 27 年にはじまった 日清戦争の時に傷病兵の後送された広島臨時陸 軍病院に医員, 看護婦をひきつれ出張するなど 東奔西走し，明治32年 7 月開かれた京都帝国大 学医科大学教授に転出している.

滋賀の第二の事件は明治29年秋の大水害であ
る．琵琶湖は瀬田川の洗堰の完成するまでは明 治時代, 例年多少の水害があり，その水位が 1 米以上上昇することはしばしばあったが明治 29 年は実に 3 米以上も湖面が上昇した。

この年は 7 月の暴風雨のため出水が多くな り， 7 月下旬に到り益々甚しくなり，其後も雨 が多く 9 月に入っても雨やまず 9 月 10 日には湖 水位が 3 米をこす最高に達した，9月13日はじ めて空が晴れて水位は減少しはじめ, 湖面がや っと常水位に達したのは11月の事である.

このため県内の死傷者は百名に及び，流失全 壊家屋3000戸，床上浸水 3 万戸以上，田畑の水 害16,000反に及んだ.

大津市の湖岸に近い家々も長期間冠水した。 又長浜の湖岸にあった私立長浜病院も大被害を 受けたが，水害のあとに米原地方に発生した赤 痢患者の多くが入院し，このため病院の損害は 帳消しにされたと記録されている。乙こは湖北 では最初に耳鼻咽喉科の出来た所で, 其後ての 病院は土地の高い所に移転し, 現在の市立長浜 病院の前身である.

\section{6）専門医のはじまりと細田忠四郎}

滋賀県に耳鼻咽喉科専門医の出来たのは大正 になってからである.

大正元年のほぼ同じ頃，大津の日本赤十字社 滋賀支部病院と彦根の公立彦根病院に新たに開 かれた耳鼻咽喉科に大杉清と三浦信一郎が夫々 赴任した。長浜では少し遅れて大正 8 年に私立. 長浜病院に藤野藤蔵が着任した。

大正年間の耳鼻咽喉科専門の開業医は大津の 元会所町に開いた倉田時治（戦時中まで）近江 八幡永原町で開いた岩瀬元治郎（昭和 35 年頃ま
で）及び大正15年彦根本町で開業した樋口敏雄 （初代）であって何れも盛業を極めている。

町立の彦根病院は大正10年彦根市立病院とな りこの耳鼻咽喉科の初代は福江咸一であり，大 正14年に設立せられた豊郷病院の初代は田中茂 太郎である。

大津赤十字病院の耳鼻科は初代大杉の 5 年の 勤務の後 2 代, 3 代は短かく, 大正 7 年住就任 した細田忠四郎は其後赤十字病院に勤務するこ と40数年に及び，滋賀県の耳鼻咽喉科の中心的 
存在となった。

細田は明治21年長野県南安曇郡梓川のほとり で生れ，大正 2 年京都府立医学専門学校を卒業 した. 前橋の赤十字病院に勤務の後, 時の京都 大学和辻春次教授と府立医専中村登両教授の推 薦により大津に着任した。

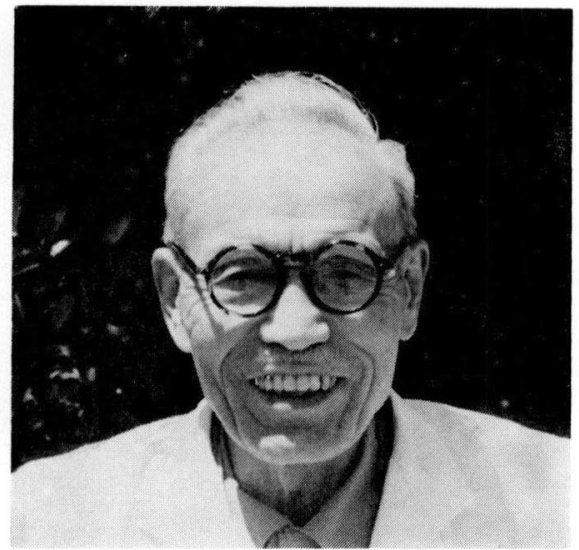

細田忠四郎（昭和26年）

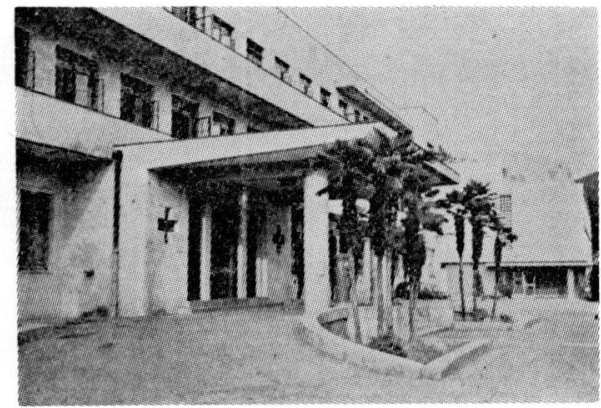

大津赤十字病院前景（昭和11年新築本館）

大正の終りより昭和のはじめにかけてての耳 鼻咽喉科の外来患者は病院外来患者全体の $30 \%$ に当る $2 \sim 3$ 万人の多数であった. 又 150 余り の病床の入院患者のほぼ15\%は耳鼻咽喉科の患 者で占められていた。
県下の他の病院の耳鼻科医はほとんど一人の 勤務であったが，ここには細田医長の下に数名 の医師があった。

大正年間，細田の指導を受けた医員は岡沢正 建, 佐藤祐太郎, 西田憲義, 杉山金吾, 横田豊 三郎, 菅野正雄, 九谷康哉, 大西輝彦があり, 昭和になって山口嘉門, 長井博通, 島本睦一郎 (昭和 5 年 3 月～昭和 14 年 8 月), 山本八郎, 横 山良雄, 久保正治, 加藤英明, 浅見一夫, 北村 保三, 鶴岡和夫, 九谷正史, 北野正, [北野修 (昭和 20 年12月～昭和23年 3 月), 阿部完市, 竹 中隆範（昭和13年 3 月～昭和 25 年 9 月, 副医長 となった)，奥田信一(昭和 23 年 1 月〜眧和 27 年 1 月, 現大津市民病院), 光吉俊明 (炤和 25 年 8 月～昭和 27 年 10 月), 日向貢 (昭和 26 年 〜昭和 38 年), 貝塚侊 (昭和 25 年10月～昭和 42 年12月, 副 医長後部長)，今村和子 (昭和 27 年10月～昭和 29 年 3 月), 小沢富孝(昭和 29 年 4 月 昭和 43 年 7 月, 副部長後部長代理となる), 石川秋津子(昭 和35年 4 月〜昭和 41 年 4 月）などがありその数 は39名に及んでいる。

門下生の菅野正雄は後に京都第一赤十字病院 院長となり, 島本睦一郎は長浜赤十字病院院長 となった，又，大西輝彦は滋賀県医師会長とな り, 北村保三は大津市市会議員となり現在滋賀 県耳鼻咽喉科医会会長となっている. 又各地で 開業したものも地域医療につくしている.

細田は明治の気骨そのもので，身を持するに 厳, 職務に精励したので, 同門会と名づけられ た門下生の追憶談には, よく叱られたなあの話 しが出る.

後述の如く滋賀県耳鼻咽喉科医会を設立し, 以来33年間その会長として運営に努力した. 其 他県立壟話学校, 中小学校の校医, 県医師会監 事，日耳鼻学会評議員など多くの職も兼務し， 昭和19年には大津赤十字病院の副院長, 昭和34 年には病院長となった。

昭和34年11月には文部大臣賞，39年10月に藍 綬集賞， 42 年 4 月には勲 4 等瑞宝章をうけ，そ の名は県下のみならず，広く県外にも鳴りひび 
いた。

閉じた。

昭和 53 年 5 月, 90 才の高令にてその生涯を

\section{7）滋賀県耳鼻咽喉科医会の誕生}

滋賀県の耳鼻咽喉科医会は昭和11年細田忠四 郎，大西輝彦二人の発起によって誕生した。

県下の専門医会としては最も早く出来たもの で, 眼科医会は戦後の昭和 24 年に, 他の科はい づれも昭和 39 年以後に発足した。

当時耳鼻咽喉科を標榜している県下医師の 31 名に案内状が出された。 6 月 21 日, 当日の会場 大津市白玉町紅葉館に出席したものは, 柕口敏 雄, 大久保政雄 (共に彦根開業), 宇野留吉 (彦 根病院), 高木功 (豊郷病院), 岩瀬元治郎 (近 江八幡開業), 九谷康哉(草津開業), 北村保三, 倉田時治，増田信一郎(共に大津開業), 島本睦 一郎，浅見一夫（共に大津赤十字病院）と二人 の発起人計13名であった。

会には滋賀県耳鼻咽喉科医会の名称がつけら れ，細田忠四郎が会長となり，幹事には湖北 （後湖東）地方は樋口, 湖南地方は大西が指命 された。

当日は県下の難聴児童の検査, 及び治療の事, 及びこの年の秋に開く予定の耳鼻咽喉科臨床会 の事が議題であった。

10月25日には第10回耳鼻咽喉科阽床会総会な らびに講演会が, 京都の両大学の後援を得て大 津赤十字病院で行われた.

この日の演題は 90 題に達し, 昼食, 休憩も殆 んど出来奴ほどで，会員も全国より集って 200 余名となった。

京都府立医大後藤五郎教授による耳鼻咽喉科 のレントゲン知識の特別講演も拍手喝采のうち に終り, 閉会後ビワ湖ホテルで懇親会が行われ た。

翌昭和12年には第 2 回の滋賀県耳鼻咽喉科医 師会総会が彦根市八景聤で行われ15名の会員出 席があった。この日には耳鼻咽喉科の治療費の 標準を定めたり，健康保険のことも相談され， 東秀雄が湖北理事となった。
この年には滋賀県衛生部, 草津壟話学校西川 校長の後援の下に会員はその地域の難聴学童の 診療に従事し, 適応者には無料, 軽減, 自費に より扁桃切除又は剔出，アデノイド切除，甲介 切除，鼻中隔矯正術などを行った。

昭和14年に会員が無料, 軽減により扁桃及び アデノイドの手術を行った記録によれば，樋口 1 , 高木 10 , 岩瀬 3 , 九谷 3 , 東 28 , 倉田 5 , 増田 3 , 長浜日赤 9 , 大津日赤 2 となっている. 其後この難聴診療, 治療のととにより医会は文 部省の表彰を受けている.

滋賀県耳鼻咽喉科医会は其後每年春には定時 総会を，夏又は秋には必要に応じて臨時の会を 持ち, 会員の親睦をはかると共に新知見の収得 につとめ, 又健康保険の発足後にはこの研究会 を持って医療内容向上を心がけた。

太平洋戦争及び終戦後の三年間は会を閉鎖し たが，23年 3 月再び開催した.

昭和27年 6 月には第10回近畿耳鼻咽喉科学会 を大津市公民館で行なった。

ての日は斉藤博士，兵博士による二つの特別 講演と72題の演題があり, 参会者は 400 名を越 えた．学会終了後ビワ湖汽船の弁天丸を借切っ て湖上パーティが行なわれ, 黄昏の湖上を回遊, 160名余りの会員の絶賛を得た。

炤和 31 年日本耳鼻咽喉科学会は 3 月 3 日を耳 の日と定め聴力保護運動に乗り出した.

滋賀の医会では昭和32年より，との耳の日の 週間には難聴の無料相談をはじめた。この年の 3 月 3 日には大津市滋賀会館中ホールに各種団 体を集め, 細田忠四郎は難聴について, 草津壟 話学校校長山口薩記は, 万うあ教育の講演を行 い，午後には襲話学校の生徒による学芸発表を 行っている. 又との年には「耳の遠い人のため に」と題する小冊子を共同で作って配布した. 其後昭和 36 年には 8 月 7 日が鼻の日と定めら 
れた。現在もこの両週間には共にポスター，パ ンフレットが配布され，耳鼻科疾患の啓蒙運動 が続けられている。

昭和39年には日本耳鼻咽喉科学会は各府県単 位に支部を置く事になり，昭和49年にはこの支 部制度が地方部会と改組された.

ために昭和 49 年細田忠四郎に代って滋賀県支 部長及び医会会長となった北村保三は地方部会 規則を定めた。
翌昭和50年度よりこの医会は日本耳鼻咽喉科 学会滋賀県地方部会及び滋賀県耳鼻咽喉科医会 として存続し, 学会活動は支部として動き, 県 内では医会として表裏一体の存在となった。

健康保険，続いて出来た国民健康保険の審査 委員には細田忠四郎，大西輝彦につづき下記の ものが歴任している。 支払基金 耳鼻咽喉科審査委員 1. 細田忠四郎 (昭和 28 年 6 月～昭和 38 年 5 月)

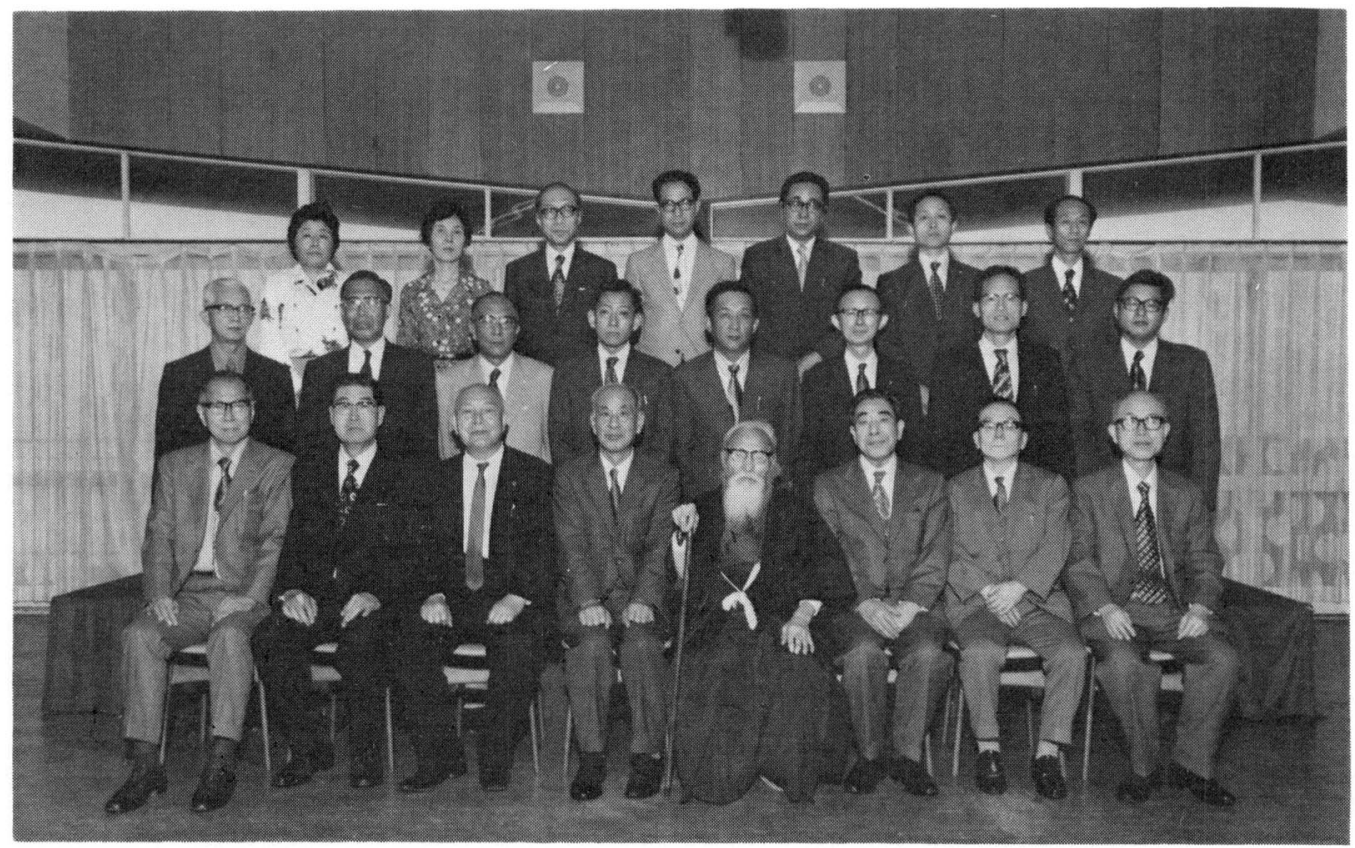

細田先生米寿祝賀記念席上の滋賀県耳鼻咽喉科医会会員と中村文雄京府大名誉教授.

（昭和50年 4 月29日，琵琶湖ホテル）

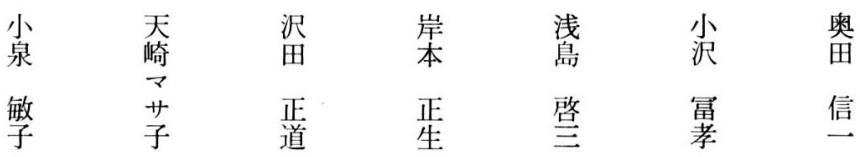

林

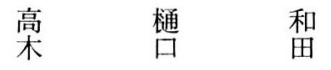


2. 増田信一郎(昭和 38 年 6 月～昭和 42 年 5 月)

3. 北村 保三 (昭和 42 年 6 月 昭和 48 年 5 月)

4. 貝塚 侊 (昭和 48 年 6 月～昭和 52 年 5 月)

5. 小沢 冨孝(昭和52年 6 月～現在 )

6. 浅島 啓三(昭和 56 年 6 月～現在 )
国保審査委員

1. 大西 輝彦 (昭和 32 年 2 月～昭和 36 年 5 月)

2. 北村 保三 (昭和 36 年 6 月～昭和 42 年 5 月)

3. 増田信一郎 (昭和 42 年 6 月～昭和 48 年 5 月)

4. 和田 耕馬 (昭和 48 年 6 月〜現在

\section{8) チフテリア}

平安朝の宮廷医家であった丹波康頼の記した 「医心方」の中にはじめて馬喉痺としてヂフテ リアの名が現われる. この康頼21世孫の丹羽全 宗は近江の生れであって豊臣秀吉の侍医ともな っている.

ヂフテリアは江戸時代にも敦和の末より文化 のはじめにかけて流行した.

明治 8 年, 東京大学医学部外科兼眼科の教師 シュルツェは実扶的利質和の名称でての臨床講 義を行って, 伝染性の疾患である事に注意して いる. 彼はこの翌年 4 才の女子のヂフテリア患 者に東京病院で気管切開を行い，一命をとりと め当時の医学会を驚かせた.

ヂフテリアは明治10年より12年にかけて全国 各地に流行し, 患者は伝染病予防規則にのっと りその地方の避病院に隔離され, 発生した家は 石炭酸により消毒された.

明治 14 年東京大学医学部内科教師ベルッは 9 才の患者に塩酸ピロカルピンの注射を用いて全 治せしめた例を報告し, 咽頭症状を主とするも のをヂフテリー，喉頭症状を主とするものをク ループと唱えるべしとの見解をのべている.

病原菌であるヂフテリア桿菌が Klebs 及び Löffler により発見せられたのは明治 16〜 7年 の事である.

明治23年北里ベーリングがヂフテリア抗毒血 清を発見するまでは内外医家はこの治療にすべ て非常に苦心した。明治27年我国ではじめてて の血清が使用され，その免疫単位も増加された が明治 30 年頃の患者の $1 / 3$ は死亡し，その直接死 因の第一位はヂフテリア菌毒素による心臓死で
あった。

明治26年滋賀県下各地の赤痢, 腸チフスの流 行と共にヂフテリア患者も 331 名に達し明治時 代としてはその前後に比を見ない多数であっ た. 明治32年以後の滋賀県に於ける患者の発生 及び死者は別図の如くである.

古くより飢饉と戦争の時には疫病が多発して いる. 今次大戦中ヨーロッパでもヂフテリアが 流行病の先頭であったように，我国でもこの間 にヂフテリアが多発している，表の如く当県で も1200名に及ぶ患者が出た。当時は医師の多く が軍医として応召し, 数少い当県の耳鼻咽喉科 医も軍務に服して少くなっており，その上治療 血清も逼迫する有様であった. 1955年より 1960 年にかけ全国的にやや患者は増加したが，当滋 賀県で発生の特に多かったのは彦根地方の紡績 工場に於ける集団発生によるものである.

ヂフテリアの発生は寒くなった11月と12月が 最高であったので, 県内の古い耳鼻科医は冬の 寒い夜に病院にかけつけてクループと云われた 呼吸困難の幼児を助けるため気管切開を行い, まんじりともしなかった当時の記憶を持ってい る.

ヂフテリアの感染防御は抗毒素免疫で十分達 成される事が分って来たので，昭和 27 年よりヂ フテリアトキフイドは百日峐とか破傷風のワク チンと共に乳幼児に接種されるようになり其上 ヂフテリア菌に対して有效なェリスロマイシン の発見もあって最近では珍らしい伝染病になっ てしまった. 


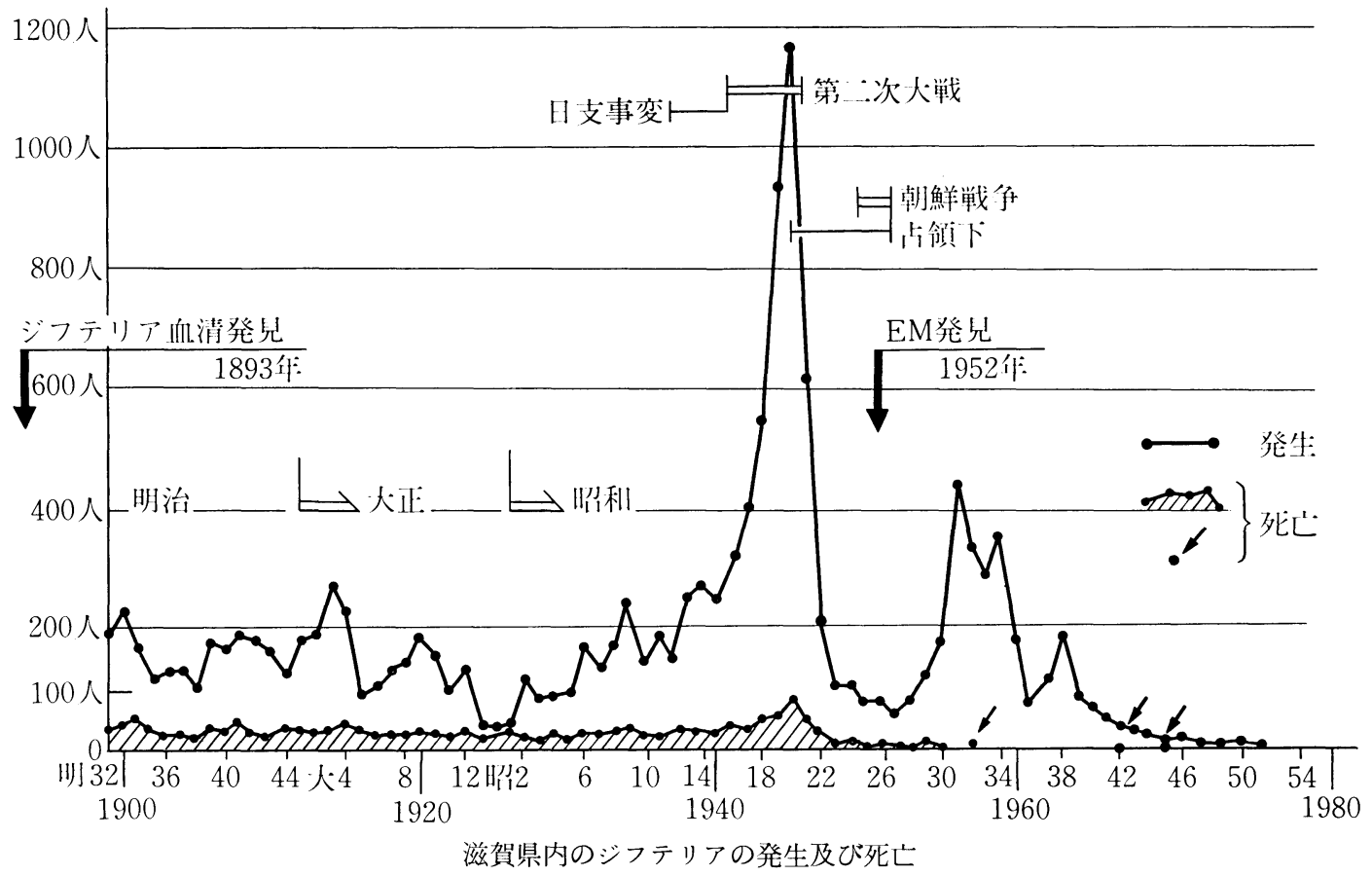

\section{9）結核と耳鼻咽喉科}

結核は古代よりあった病気である。我国では 江戸時代には労咳と呼ばれていて, 主として思 春期の青年男女が犯されたので心の病い, 即ち 心気症と混同されていた。

ヨーロッパでは19世紀に人々の都市集団化, 産業革命の進歩と共に多発して，「白いペスト」 として人々の恐怖の対称となった。

英米より遅れて産業革命の起った我国では明 治, 大正期以後結核が猛威をふるうようになり, 特に昭和 10 年より昭和 25 年までの 15 年間では結 核が我国の死亡順位の首位を独占して来た。

水にめぐまれた農業県滋賀県は伝統的な綟, 麻織物を産したが, 明治以後は綿織物, 昭和に なり人絹, ナイロンの工場も多く作られ, 工員 も増え結核患者の数も次第に増して来ている.

滋賀県に於ける結核患者の死亡率は別図の如 くであって昭和 25 年まで年間の死者は, 1000名 より1500名に達している. 患者の数はての10倍 にも達していたろうと推定され, 大戦中の統計
は欠けている．ての間にはヂフテリアのような 多発は無くとも, 患者, 死者は相当多かったて とと推定される.

明治38年近江八幡商業の英語教師として来日 した米人ウイリアム・ボーリスはこの結核の多 いのを見て, 大正 7 年近江八幡の鶴翼山のふも とに自然療法のための近江サナトリウムを建て た. 之は欧米のサナトリウムを範としたもので 当時この種の結核療養所は我国には 1,2 しか 無かった。

明治41年 8 月には結核菌を発見したローベル トコッホが北里秀三郎などと共に琵琶湖の観光 のため大津石山に来遊し湖上遊覧を楽しんだ.

この頃より結核に対する人々の関心も次第に高 まった。

大正 12 年には当時の大津赤十字病院の伊藤秀 院長は海外視察により, 欧米の結核対策を知り, 院内に結核病舎を新築している.

県には其後, 比良園, 紫香楽園などの国立療 


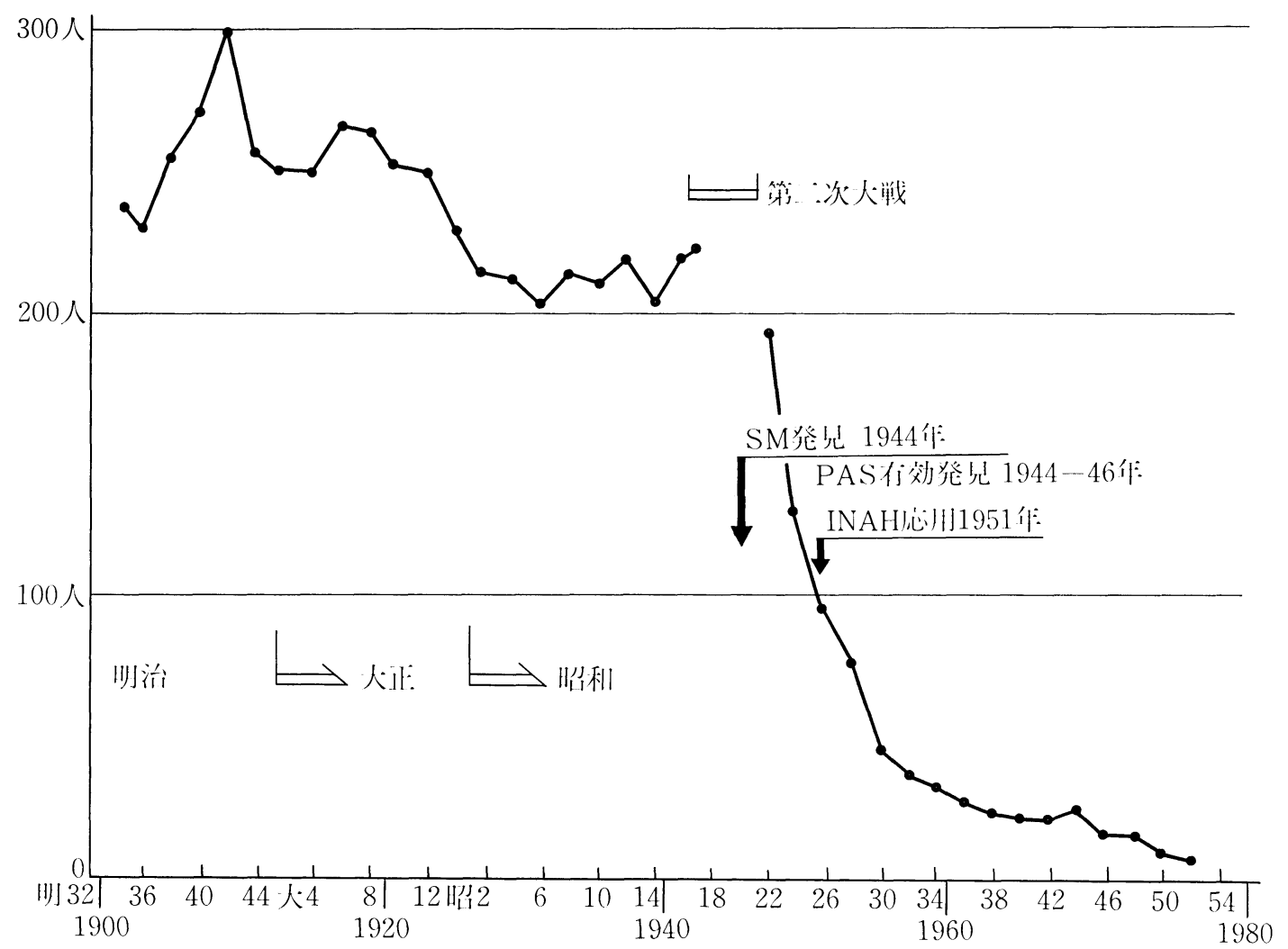

滋贺県内絬核死亡率 (人口10万比)

養所が建てられた。

当時声がかすれる様になれば人々は先一゙結核 が喉頭に来たのではないかと恐れたもので，喉 頭結核の発生は全結核患者の14２0\%に及んで いた。

耳鼻科医はこの㬋頭結核患者のはげしい燕下 痛の治療に苦心をした。

京都にも結核患者が多く, 京都府立医科大学 の中村登教授は昭和 9 年に, 京都大学後藤光治 教授は昭和18年に夫々「喉頭結核」と題するモ ノグラフを出版した。共に当時の早期発見, 治 療の苦心のあとがうかがわれる。 又炤和24年に は中村文雄教授会長の下で京都に開かれた第50
回日本耳鼻咽喉科学会では, 後藤光治教授によ り喉頭結核の宿題報告が行われている.

其後難病であった喉頭結核も1944年発見のス トレプトマイシン, 次いでパス, INAHなどの 有効な薬物が次々に出来て，劇的な効果をおさ めた。

当時の保健所の主な仕事は当時結核対策であ って, 其後の BCG 接種などの予防処置も有効 であった。併し現在でも結核の発生は跡をたた ず，数年前には和歌山の一耳鼻科医院に於ける 中耳結核の多発事件があった。今喉頭結核はほ とんど見られないけれども結核は決して忘れて はならない疾患である。

\section{0）造鼻術と顔面形成}

江戸時代には望童と云われた 細工人があっ て，入歯を作っていた。 ての家の看板には其上
入目ばかりでなく入鼻も作ると書かれてあった。 当時は梅毒で鼻の落ちたものが相当あったた 
めである.

明治 2 年英人ウイルスが我国ではじめて造鼻 術を行った時は新聞にも報ぜられ，湯島に順天 堂病院を明治 6 年に開いた佐藤尚中は日本人で はじめて造鼻術を行っている.

刑罰のため鼻をそがれた者が多かった古代イ ンドでは額の皮膚から鼻を作る方法がその医書 スシュタに記されており，16世紀にはイタリア 法と呼ばれる腕の皮膚から作る鼻の再建手術が 考えられた。

大戦中我軍の将兵にも顔面戦傷が多かったの でこの整形手術を創案したのが滋賀県今津生れ の斉藤勤である，七高, 京大卒業後軍医となり 星野教授の指導を受け, ドイッに留学, 昭和 15 年の日本耳鼻咽喉科学会及び, 昭和 27 年大津市 公民館で行った第10回近畿耳鼻咽喉科学会で顔 面整形手術の報告を行なっている，学会では映 画により造鼻術をはじめとする数々の症例の供 覧が行われ，このフィルムは今も京都大学に残 されている.

斉藤軍医中将は昭和23年大津市膳所に開業, 大津市教育委員長, ライオンズクラブ会長にも なった。

大戦後大津に米軍が進駐した頃は米人の高い 鼻にあこがれ隆鼻術を希望する婦人が大津赤十 字病院を多く訪れたので, あまりひどい鞍鼻に
対しては象牙による隆鼻術が行われた. 又当時 は街娼婦も多く, 写真のような梅毒で鼻の一部 の落ちた婦人が来院したので頓部の皮膚を印度

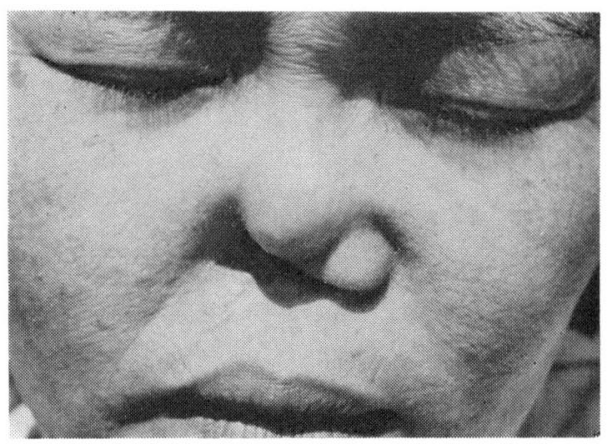

梅毒で欠いた鼻

法によって転移し, 昭和39年の滋賀県耳鼻咽喉 科医会で小沢冨孝が之を発表している.

鬼唇, 口蓋裂の手術は最初は外科で行われて いた． 往時にはひどい奇型の乳児をつれた親族 代表が外科の医長の所へ来て「先生どうか思い 切って手術をして下さい」と願っていた記憶が 生々しく残っている.

其後鼓室形成術の様な微細手術のうまくなっ た耳鼻科医がこの手術を手がけるようになり， いろいろの補助切開, 鼻腔栄養法の進歩もあり, ほとんど手術跡の見られない様な出来ばえとな って来た。

\section{1）湖国と耳の感染症}

古代のギリシヤ時代にヒポクラテスが子供は 耳漏に苦しみ，大人は襲に苦しむと云っている ように現在でも小児の70 $80 \%$ は度は中耳炎 を経験するもので耳の感染症は耳鼻咽喉科医に とって最も多い疾患である.

外耳道炎は温暖, 多湿の所に多く, 水泳を好 む人にはその発生率は 5 倍になると云われる. 中心に琵琶湖をかかえた滋賀県では夏には外耳 道炎, 冬の上気道感染症の多い頃には中耳炎が 多発し, 特に抗生剂のない頃には, 耳鼻咽喉科 の外来には多くの患者がおしかけた。
中耳炎も順調な経過をとれば 2 週間ほどで治 癒したが, 麻疹, インフルェンザ, 肺炎などの 体力を弱める疾患などのあとには乳様突起炎, 頭蓋腔内合併症も多く, 当時の小児の死因統計 の中には耳及びその合併症の項があるほどであ る.

大正 7 年には時の長崎医大教授小室要は耳性 頭蓋腔内合併症の宿題報告を行っている.

この頃米国でも大病院の40例の死亡者のうち 1 例は耳性頭蓋腔内合併症であったと記されて いる. 
当時の耳鼻科医は耳漏を止めるために色々の 薬物を苦心して用い，その起炎菌よりワクチン を作って免疫療法を行う事が最高のものであっ た. 又頭蓋内合併症を防ぐため, 乳様突起開放 手術は扁桃手術に次いで多く行われた手術であ

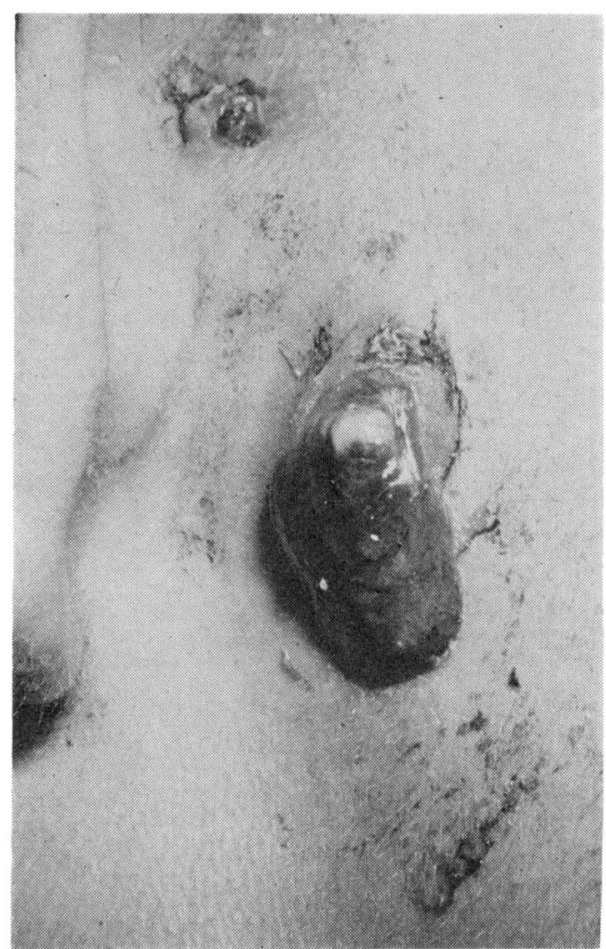

左耳後部の肉芽
る. 乳突部の発赤腫脹ばかりでなく写真の様に 耳後に肉芽病変が現われるような患者も20年ほ ど前には見られたものである．現在では耳の後 に図の様な手術の跡の残っている人々も少なく なっている。

又耳介や鼻の丹毒も危険な事が多く，虚弱児 に稀に見られた水癌（Noma，Wasserkrebs） は総て死亡した。

併し大戦前に我国にもたらされた Sulfa 剤は 丹毒などの感染症には劇的な効果があり，その 上戦後出廻ったペニシリンをはじめとする抗生 物質により耳性頭蓋腔内合併症の治療はほとん ど解決された，又副腎皮質ホルモンなども出来 たので耳鼻科医の長年苦労した耳漏も長期間に わたるものは少くなった。

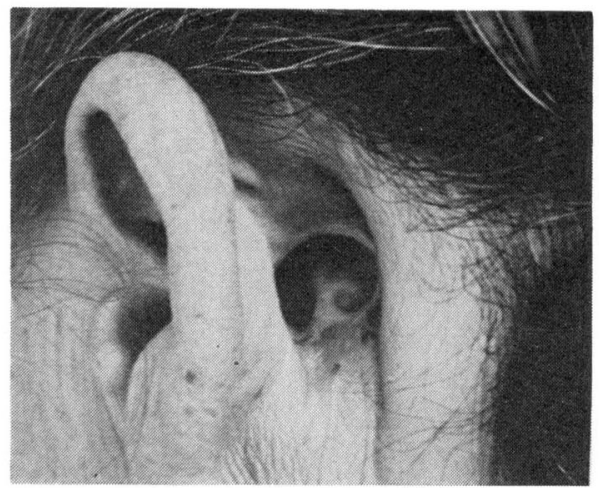

乳様洞の手術跡

\section{2）手術方法の变遷}

既に印度では 5 世紀に扁桃手術が行われた記 載があるけれども，近代の扁桃手術は 1860 年 Mackenzie の作ったギロチン式手術器械によ り広く世界的に行われるようになった。

滋賀県でもはじめは扁桃切除術が最も広く行 われたもので, 其後アデノイド切除が加わり, 扁桃摘出術が主として行われる様になったのは 戦後のととである.

小，中学校の休みとなる夏休みとか短い春休 みには耳鼻科医は連日の様に多くのこの手術を 行ったものである.

併し咽喉の感染症も早期に 治癒する様にな
り, 又幼小期の扁桃は生理的に肥大し, 活発な 免疫機能を営んでいることが分って来たので， 次第に病的なもの以外の手術は行われなくなり つつある。

緎維工業の盛んであった滋賀県ではその塵埃 が細菌感染症を一層重くするのであろうか. 結 核と同様その工員には蓄膿症が多かった。

又, 一般家庭でもその食生活, 衛生状態が悪 かったのであろう．今に数倍する蓄膿症の患者 があった，上顎洞ばかりでなく，篩骨洞，前頭 洞にも病変のあるものがあり，キリアン式，次 で荻野式前頭洞手術もよく行われた。 
耳の手術を成功するため, 先づ鼻内矯正, 副 鼻腔炎の手術を行ったのち耳の手術にとりかか らねばなら双人々も多かった。

耳の伝音機構の解明, Audiometer の開発, 双 眼顕微鏡の進歩により，1952年（昭27年）ドイ ツの Wullstein, Zöllnerにより唯炎症を無くす るだけではなく，聴力の回復を目指した鼓室形 成術が創案された。とのアイデアは我国の後藤 修二，風間保彦等も持っていたもので夫々独自 に色々の発表があった。

大津赤十字病院でも耳漏の止った鼓膜の小穿 孔に対しては羊膜と辺縁焼灼による閉鎖術が先 づ試みられ，それ以上の病変に対して Storz の 3 倍ルーペを用いて鼓膜形成術, 鼓室形成術 が行われた。

昭和32年より 42 年までにここで行われた耳の 手術は 700 例に及び色々の方法で鼓膜及び鼓室 形成が試みられた. Carl Zeiss の手術用顕微鏡 が大津赤十字病院に購入されたのは昭和 41 年の ことで，現在では県下各病院には手術用顕微鏡 がそなえられ，耳鼻科のみならず眼科，血管外 科などの必須のものとなっている。

耳鼻咽喉科領域の悪性腫瘍は抗生剂発見以前 は術後の成績も悪く, 島本睦一郎長浜日赤院長 の記録に上顎癌の手術で救うことの出来た例は 二例のみであったと記されている.

大津赤十字病院では昭和 30 年より 40 年にかけ ての 10 年間に 28 例の上顎癌（男女ほぼ同数）と

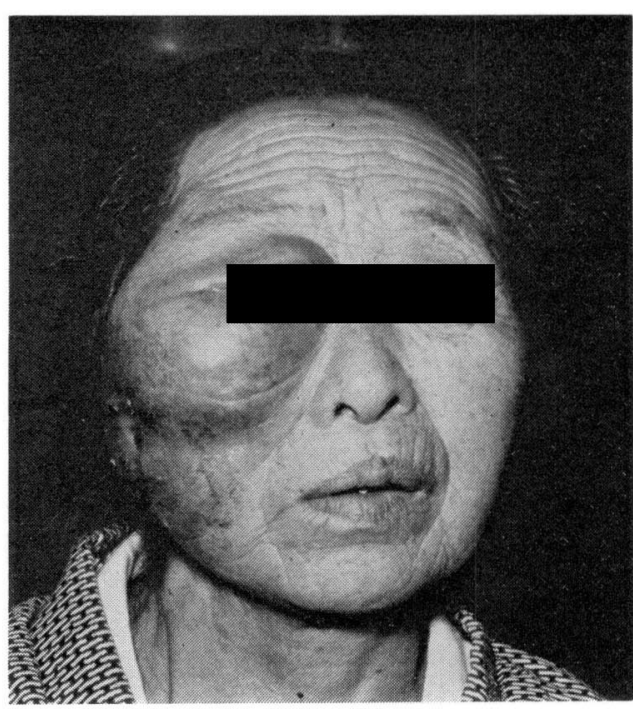

進行した上顎癌

18例の喉頭癌（男性のみ）の入院手術が行われ ている，手術方法，抗生剤のみならず， レ線照 射法, 抗癌剤などの進歩もあって前者では約 $1 / 3$, 後者では約半数が救命出来た.

又との間, 鼻咽頭腫瘍 5 , 舌癌 3 , 口内癌 2 , 食道癌 2 , 聴器癌 1 , 扁桃肉腫 5 の症例があっ たが何れも早期受診でなく予後不良であった。

現在，喉頭腫瘍はファイバースコープ等によ り早期発見され，放射線のみで治療するものが 多くなり，他の頭頸部腫瘍も CT（コンピュー タートモグラフイー）などの進歩もあって早期 に発見治療されるようになって来た。

\section{3）学 校 保 健}

明治 5 年に学制がしかれた我国の学校では明 治初期にはコレラ, 天然痘の予防, 学校の衛生 設備などの保健対策がたてられた。

明治後期には学校医とか身体検査の規定が行 布され, 耳鼻科疾患としては聴力, 耳疾の項目 がある. 当時は懐中時計の聴取距離で聴力が測 定され，10才未満は施行せず, 尋常小学校では 省略してもよいとととなっていた．

昭和11年に発足した滋賀県耳鼻咽喉科医会で
は前述の如く文部省が学童生徒の聴力及び耳鼻 咽喉科疾患に対して本格的に取りくむ以前に県 下小学児童の 難聴の検疹及び治療に取りくん だ.

当時は咀語法によって行われた聴力検査は昭 和 33年になって Audiometer により 行なわれ る様になり聴覚障害児の発見がより確実になっ て来た。

戦前には学校検診の主力が中等学校にむけら 
れていたが次第に年少者に注意がむけられる様 になった．大津市では昭和24年より各小学校も 耳鼻科医が検診を行う様になり，昭和45年より は公立幼稚園の検診もはじめられた。

戦前には 1 クラス, 50 人の小学学童の中には 必ず数名の鼓膜穿孔，耳漏のあるものが発見さ れたものが年と共に減じて来ている．現在大津 市の統計では中耳炎の見られるものは幼稚園で 2000 人に 1 人以下となっており, 小学, 中学で はさらに少なくなっている.

又，検診のはじまった昭和 30 年頃には $5 \%$ 或 はそれ以上に発見された蓄膿症も現在では $1 \%$ 以下に減じており, 変ってアレルギー性鼻炎が 増えつつある.
現在毎年 4 月より 6 月までに行なわれている 学校検診は最も耳鼻科医の多い大津市でも一名 が数校の検診を受持っている. その担当数は 4000名に近い医師もあり, 郡部では7000名に及 ぶ医師もあって, 両耳, 鼻, のどと検診部の多 い上，微細な部位の観察であるためての春の耳 鼻科医の苦労は他科の校医に仲々理解してもら えないのである。

これからの学校保健の最大の課題は, 耳鼻科 の定期検診の全県下への普及である.

学校数は増々増えて行く, 又県内には交通不 便の僻地校も多い. 容易に解決は出来ない問題 が多いが，おしすすめなければならない。

\section{4）西川吉之助と草津壟話学校}

近世まで襲啞者は農業か手工業についている ものもあったが，和漢三才図絵にあるでとく乞 食をしているのが市井に見られる姿であった。

幕末の頃には寺小屋の十軒に一軒は襲児や盲 児が学びはじめていた様子である.

明治11年に京都に盲啞院が作られ，こてでは 先づ手勢と云われた手話に次で，書きてとばの 教育が行われた。

滋賀県に龍話学校が出来たのは昭和 3 年のと とで近江八幡の豪商, 西川吉之助の努力による ものである。

北海道オショロで鰊の漁業問屋を営んでいた 西川家を継いだ吉之助は父の在世中は世界各地 を巡り，滞米 9 年に及んだ。帰国して京に住ん だ頃，三女はま子が生れたが言葉を発しなかっ た。 彼女は 3 才になった明治45年, 京都府立医 学専門学校, 耳鼻科部長中村登博士の精密な検 查を受けた所，壟児とわかり，特殊な教育法の 必要をとかれた。

吉之助は早速京都盲啞院の襲涇部の授業を参 観したが，その手話法を見て暗い印象を受けて 帰った。彼は襲教育の内外諸国の文献を求め Volfa Review の口話法を知り, 米国 Wright
のオラールスクールの通信教育により，はま子 及び近在の壟児にこの教育をはじめた。

ての頃我国で口話法教育を行っていたのは東 京の米人の作った幼稚園と, 名古屋の壟学校の みであった。

父の熱心な教育により口話法の上達したはま 子は小学校, 高等女学校も普通に入学した。

日本耳鼻咽喉学会関西地方会では, 大阪医大 加藤享教授が西川氏を紹介してての口話法を解 説し、はま子が口話を実演した。

昭和 3 年草津の郡農会の養虫室でての西川を 初代校長として，龍でなく聾話と名づけらた県 立草津竩話学校が発足した。乙の時は 6 名の教 員に生徒は16名であった。昭和 5 年に校舎が新 築され, 昭和10年には生徒数が100名となった。 昭和 24 年には全国に先がけて永島 $49 \mathrm{~A}$ オーヂ オメーターを購入し全生徒の聴力検査が行わ ている.

この学校の耳鼻咽喉科の専門校医は最初より 細田忠四郎が受持ち, 昭和 $7 \sim 8$ 年前より九谷 康哉が代った。乙の児童生徒の失聴原因は滋賀 の山間, 僻地は血族結婚が多いため之によると 思われる壟者が多かった. 其上抗生物質の無か 
った頃は脳膜炎，熱病，中耳炎により難聴にな る者も多かったので昭和33年には児童生徒数は 最高の 225 名に達した。其後県の人口増加にも かかわらず生徒数は次第に減じはじめた. 現在 では早期教育のため 3 才児より生徒は在籍して いるが，その数は 100 名前後に減少している.

現在の失聴原因は不明のものが $45 \%$ ，先天性 のもの34\%である. 後天性のものには脳膜炎に よるものはなく，難産によるもの $6 \%$, 中耳炎
のもの $5 \%$, 熱病によるもの $2 \%$ とっていて， 一時 増加していたストマイ難聴者は $1 \%$ 減 り，近年になって判明した母親の妊娠中の風疹 による難聴者が $8 \%$ と増えている.

この教育方法も残聴を利用した補聴器教育が 3才児よりはじめられていて, 現在では口話法 を主体としたトータルコミュニケーションの指 導が行われている.

\section{5）医師の教育と滋賀医科大学の開講}

明治13年滋賀県では公立大津病院に医学校を 作り, 満 3 年の医師育成をはじめたが, 明治15 年 6 月に文部省の医学校通則の制定により惜し

\section{くも廃校になった。}

公立大津病院にはじまった日本赤十字社滋賀 支部病院は昭和 21 年より昭和 40 年まで医師実地 修練指定病院となっていて, 当時インターンと 云われた医師が実習をうけ，その数は 238 名に 達した. この中には大学教授になった医師もあ り, 現在の県内各地の中堅医師となっているも のも多い.

昭和35年頃より全国各地の赤十字病院に労働 争議が起り，ために奈良赤十字病院は閉鎖され た. 大津赤十字病院もはげしいストライキの嵐 に巻き込まれ，36年 8 月細田忠四郎院長は退職 した.

昭和38年 8 月に京都大学耳鼻咽喉科教室後藤 光治名誉教授が大津赤十字病院院長として就任 した. 昭和40年10月後藤院長は京都に開かれた 国際オージオロギー学会会長となり, 又続いて 東京で開催の第 8 回国際耳鼻咽喉科学会には大 津赤十字病院より. 後藤, 小沢, 貝塚の 3 名に より二題の展示発表が行われた.

昭和34年に耳鼻咽喉科部長となった貝塚侊と 昭和 43 年に耳鼻咽喉科部長代理となった小沢富 孝の頃の医員は日向貢, 今村和子, 石川秋津子 ( 3 名の年代は前述), 藤井花子 (昭和 38 年〜昭 和 41 年), 西村武重 (昭和 42 年 1 月～昭和 43 年 7 月, 現在京都第一赤十字病院耳鼻咽喉科部長),
伊達敬一（昭和 43 年 1 月〜昭和 43 年 7 月）であ る.

昭和 43 年11月には東文生が第 7 代の耳鼻咽喉 科部長となり現在に到っている. その医員は岸 本正生 (昭和 44 年 1 月 昭和 48 年12月), 北嶋和 智 (昭和 44 年 5 月～昭和 45 年 8 月), 中野紘介 (昭和 46 年 4 月～昭和 47 年 2 月), 八木伸也（昭 和 46 年 4 月～昭和 48 年 4 月), 近森義則 (昭和 47 年 1 月～昭和 48 年11月), 矢沢代四郎 (昭和50年 6 月～昭和 53 年 3 月), 松原秀春 (昭和 50 年 9 月 ～昭和53年 3 月), 広瀬章子 (昭和52年 4 月～昭 和53年 4 月), 大川正直 (昭和55年 8 月～昭和 56 年 4 月), 大村正樹 (昭和 53 年 4 月 現在), 渡 辺吉弘（昭和55年 4 月〜現在）である.

昭和50年 2 月には大津赤十字病院は滋賀医科 大学関連教育病院の指定を受け, 病院設備を拡 充, 全病床は766となった.

この年後藤光治院長は滋賀医科大学の参与と なり，53年 4 月には大津赤十字病院名誉院長と なった。

昭和49年10月守山市の仮校舎に開学した国立 滋賀医科大学は昭和 50 年 5 月 2 日大津市と草津 市の南にある丘陵地带 23 万平方米余りの広大な 土地に次々と大学及び附属病院を建てた. 昭和 53年 4 月には耳鼻咽喉科学の講座が設置され, 教授には京都大学耳鼻咽喉科助教授の北原正章 が就任, 助教授には京都大学講師斎藤春雄, 講 師北島和智, 助手竹田泰三, 助手矢沢代四郎, 助手松原秀春が教室員となった。 
53年10月には外来診療がはじまり，其後北野 化, 北野畺由美, 北野博也の入局があり, 本年 度には滋賀医大第 1 回卒業生の児玉章，水上千 佳司が入局した。

昭和54年の 4 月には北原教授は日耳鼻学会地 方部会会長及び日本耳鼻咽喉科学会滋賀県地方 部会選出評議員となった。
本年 5 月の檜学京都大学教授の主催する第 82 回日本耳鼻咽喉科学会総会では長年の研究成果 の「メニェール病の基礎と臨床」の宿題報告を 京都会館で発表した。

\section{$\left(\begin{array}{ll}\text { 別刷請求先 }: \text { 貝塚 } \text { 伙 } \\ \bar{\top} 520 \text { 大津市浜大津 } 1 \text { 丁目 } 1-5\end{array}\right)$}

\section{日本耳鼻咽喉科学会滋賀県地方部会名簿}

\begin{tabular}{|c|c|c|c|c|c|c|}
\hline \multicolumn{2}{|c|}{ 氏 } & 名 & \multirow{2}{*}{$\begin{array}{l}\text { 干番号 } \\
520\end{array}$} & \multirow{2}{*}{$\begin{array}{r}\text { 医 療 機 関 所 在 地 } \\
\text { 大津市中庄 } 2 \text { 丁目18-17 }\end{array}$} & \multicolumn{2}{|c|}{ 電話番号 } \\
\hline 浅 & 島 & 啓 三 & & & $(0775)$ & $22-3219$ \\
\hline 東 & & 秀 雄 & 526 & 長浜市元浜町7-5 & $(0749)$ & $62-6106$ \\
\hline 東 & & 文 生 & 520 & 大津赤十字病院大津市長等 1 丁目1-35 & $(0775)$ & $22-4131$ \\
\hline 伊 & 司 & 蔵光子 & 520 & 大津市粟津町10-3平野ビル $2 \mathrm{~F}$ & $(0775)$ & $34-4030$ \\
\hline 大 & 川 & 正 直 & 520 & 大津赤十字病院 大津市長等 1 丁目1-35 & $(0775)$ & $22-4131$ \\
\hline 大 & 村 & 正 樹 & 520 & "1 & & " \\
\hline 岡 & 本 & 康比古 & 520 & 大津市におの浜 2 丁目2-5-106 & $(0775)$ & $25-7451$ \\
\hline 奥 & 田 & 信 一 & 520 & 大津市民病院 大津市本宮 2丁目9-9 & $(0775)$ & $22-4607$ \\
\hline 小 & 沢 & 冨 孝 & 520 & 大津市錦織 2 丁目 2-27 & $(0775)$ & $23-1617$ \\
\hline 貝 & 塚 & 侊 & 520 & 大津市浜大津 1 丁目 1-5 & $(0775)$ & $22-7897$ \\
\hline 岸 & 本 & 正 生 & 525 & 草津市野村町560-4 & $(0775)$ & $63-1177$ \\
\hline 北 & 野 & 修 & 524 & 守山市守山町1052 & $(0775)$ & $82-0107$ \\
\hline 北 & 野 & 仁 & $520-21$ & 滋賀医科大学 大津市瀬田月輪町 & $(0775)$ & $48-2261$ \\
\hline 北 & 野 & 博 也 & "1 & "1 & & $1 "$ \\
\hline 北 & 野 & 真由美 & "l & "1 & & " \\
\hline 北 & 村 & 保 三 & 520 & 大津市中央 1 丁目 3-2 & $(0775)$ & $22-3973$ \\
\hline 北 & 原 & 正 章 & $520-21$ & 滋賀医科大学 大津市瀬田月輪町 & $(0775)$ & $48-2260$ \\
\hline 北 & 嶋 & 和 智 & "I & "1 & & " \\
\hline 九 & 谷 & 康 战 & 525 & 草津市大路1-18-31 & $(0775)$ & $62-2270$ \\
\hline 小 & 泉 & 敏 子 & 520 & 大津市鳥居川町6-22 & $(0775)$ & $37-3023$ \\
\hline 神 & 山 & 五 郎 & $527-01$ & 近江温泉病院 愛知郡愛東町百済寺 & $(07494)$ & 4) $6-1125$ \\
\hline 斎 & 藤 & 春 雄 & $520-21$ & 滋賀医科大学 大津市瀬田月輪町 & $(0775)$ & $48-2261$ \\
\hline 沢 & 田 & 正 道 & 526 & 長浜市高田町11-6 & $(07496)$ & 6) $3-2830$ \\
\hline 園 & 田 & 隆 & 522 & 彦根市京町 2丁目3-37 & $(07492)$ & 2) $3-8581$ \\
\hline 園 & 田 & 裕 & 527 & 八日市市八日市町2-15 & $(07482)$ & 2) $2-2412$ \\
\hline 高 & 木 & 功 & 527 & 八日市市浜野町3-15 & $(07482)$ & 2) $2-1089$ \\
\hline 竹 & 田 & 泰 三 & $520-21$ & 滋賀医科大学 大津市瀬田月輪町 & $(0775)$ & $48-2261$ \\
\hline 天 & 崎 & マサ子 & 520 & 大津市梅林 1 丁目 $4-23$ & $(07485)$ & 5) $2-2138$ \\
\hline
\end{tabular}




\begin{tabular}{|c|c|c|c|c|}
\hline 民 & 名 & 干番号 & 医療機関所在地 & 電話番号 \\
\hline 端 & 達 郎 & $529-16$ & 蒲生郡日野町大窪983 & (07485) 2-0516 \\
\hline 筩 口 & 敏 雄 & 522 & 彦根市本町 1 丁目9-20 & (07492) $2-1828$ \\
\hline 瀬 & 章 子 & 520 & 大津赤十字病院 大津市長等 1 丁目1-35 & (0775) $22-4131$ \\
\hline 田 & 信 明 & 520 & 大津市中央 2 丁目 4-14 & (0775) $22-3454$ \\
\hline 原 & 秀 春 & $520-21$ & 滋賀医科大学 大津市瀬田月輪町 & (0775) $48-2261$ \\
\hline 井 & 亮 子 & $520-23$ & 野州郡野州町小篠原町2229-184 & (07758) $8-3985$ \\
\hline 沢 & 代四郎 & $520-21$ & 滋賀医科大学 大津市瀬田月輪町 & (0775) $48-2261$ \\
\hline+4 & 松 郷 & 528 & 甲賀病院 甲賀郡水口町鹿深3-29 & $(07486) \quad 2-0234$ \\
\hline 田 & 耕 馬 & 528 & 甲賀郡水口町 1 丁目 6-11 & $(07486) \quad 2-0389$ \\
\hline 辺 & 吉 弘 & 520 & 大津赤十字病院 大津市長等 1 丁目1-35 & (0775) $22-4131$ \\
\hline
\end{tabular}

\section{おわりに}

北原教授のおすすめと，滋賀県耳鼻咽喉科医会の北村保三会長はじめ会員皆々様の御協力により ての歴史が出来.上った.

もとより私の浅学，非才の上，短期の調査であったので誤りや書けなかった所が多いと思われる ので今後も御教示を御願いしたい，又，文中は敬称を省略させて頂いた。

本年 3 月 19 日, 私は共に湖北の耳鼻咽喉科の草わけである東秀雄先生, 島本睦一郎先生をての取 材のため御訪ねして数々の貴重な資料を得た.

ての時には77才の高㱓であったにもかかわらず御元気に開業診療をされていた島本先生は，学校 検診などで耳鼻科医の最も多忙となった 6 月 18 日急逝された.

先生は昭和 5 年京都府立医大卒業後直ちに大津赤十字病院勤務, 日支事変中赤十字の要請により 戦時救護船に乗船， 2 年間南支，青島などの各地を廻られた.

昭和14年より長浜赤十字病院に勤務，昭和18年副院長，昭和 36 年に院長となり，昭和 41 年院長を 退いた後も44年末まで嘱託としてててで耳鼻咽喉科の診療をつづけられた。

いつまでも童顔，温厚であって赤十字と医療の奉仕に一生を捧げられた先生の御冥福を心より御 祈りしたい.

\section{主 要 文 献}

1）医学の跡をたづねて（その 27 滋賀）: 伊良子光義 昭和35年，実験治療 343 号.

2）滋賀県医師会70年史，昭和33年，滋賀県医師会.

3）滋賀県医師会25年のあゆみ. 昭和50年, 同上.

4）明治前日本医学史（第 4 巻）1964年，日本学士院 明治前日本耳鼻咽喉科学史, 田中助一.

5) 日本耳鼻咽喉科全書（第 1 巻）昭和 8 年, 克誠堂 書店. 世界に於ける耳鼻咽喉科学史, 金杉英五郎. 日本に於ける耳鼻咽喉科学史, 冨士川游. 日本に 於ける近代耳鼻咽喉科学史, 岡田和一郎.

6）滋賀県耳鼻咽喉科医師会会誌，昭和11年より.
7）京都府立医科大学 80 年史, 昭和 30 年, 京都府立医 科大学.

8）京都府立医科大学百年史, 昭和49年, 同上百年史 委員会.

9）京都の医学史，昭和55年，京都府医師会.

10）京都大学医学部耳鼻咽喉科教室, 同空会報 4 , 後 藤光治教授退官記念号, 昭和38年.

11）森本正紀教授退官記念論文並に回顧録，1976年, 京都大学耳鼻咽喉科教室.

12）滋賀県諸統計資料.

13）学校保健百年史, 昭和 48 年, 文部省. 
14）耳鼻咽喉科の学校保健, 昭和 49 年, 日本耳鼻咽喉 科学会学校保健委員会.

15）創立四十年史, 昭和46年滋賀県襲話学校.

16）西川吉之助, はま子の業績の今日的評価，1981年, 滋賀大学教育学部特殊教育研究室.

17）日本赤十字社滋賀支部誌, 昭和 8 年, 日本赤十字 社滋賀文部.

18）彦根市立病院 50 年史, 昭和 17 年, 彦根市立病院.

19）獅子将軍（斎藤勤回顧録）昭和 41 年斎藤きよへ.

20）日本耳鼻咽喉科史年表昭和54年，日本耳鼻咽喉科
学会.

21）近畿産科婦人科医界沿革史, 昭和 43 年, 近畿産婦 人科学会.

22）大阪の耳鼻科医の古い先輩たち, 昭和51年, 磯野 嚴, 大塚薬報.

23）耳鼻咽喉科学史, R. S. Stevensun \& D. Guthie 昭和34年, 小野譲訳.

24）鼓膜を中心とした耳科学小史，貝塚伙，昭和43年, 耳鼻臨床. 


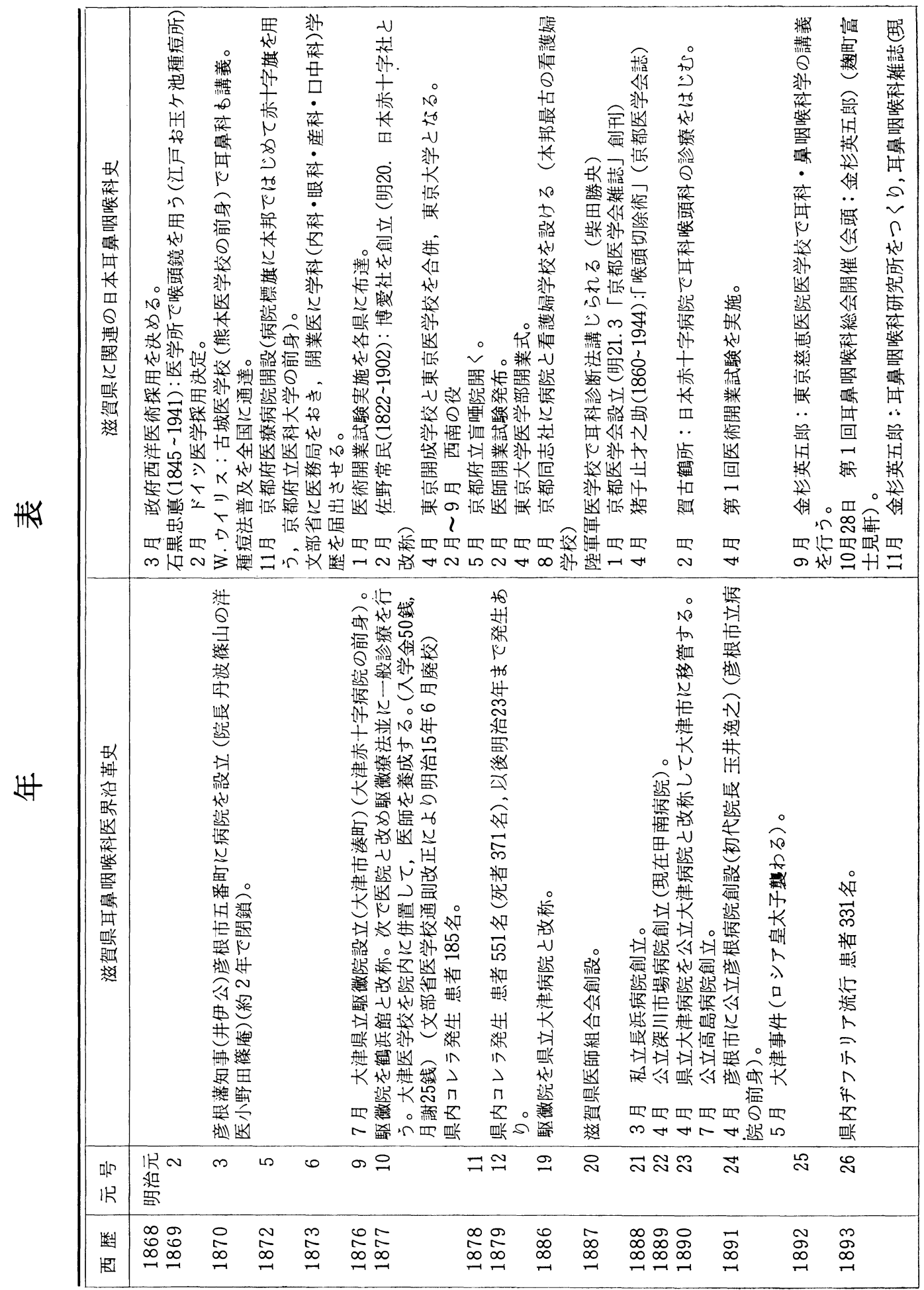




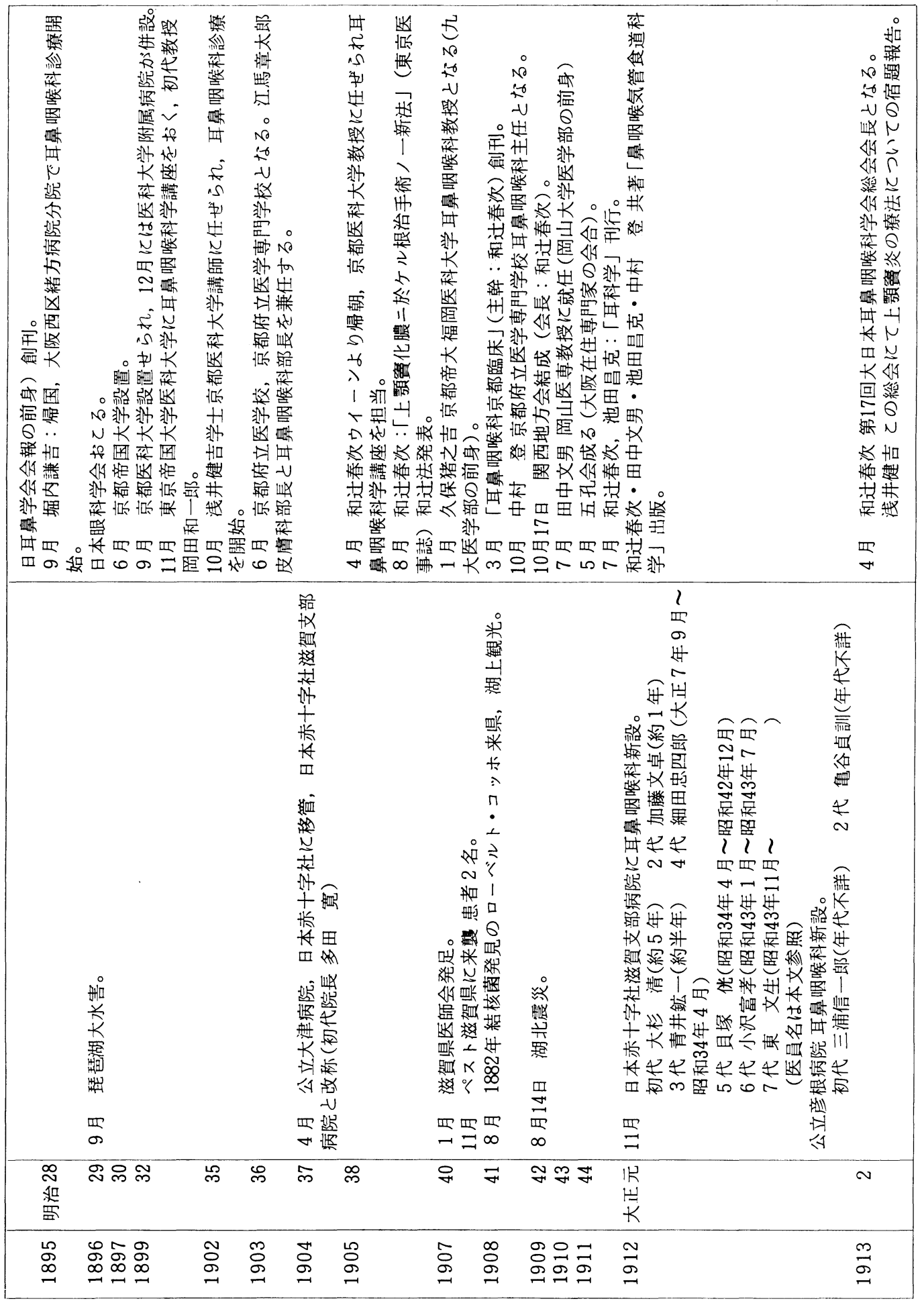




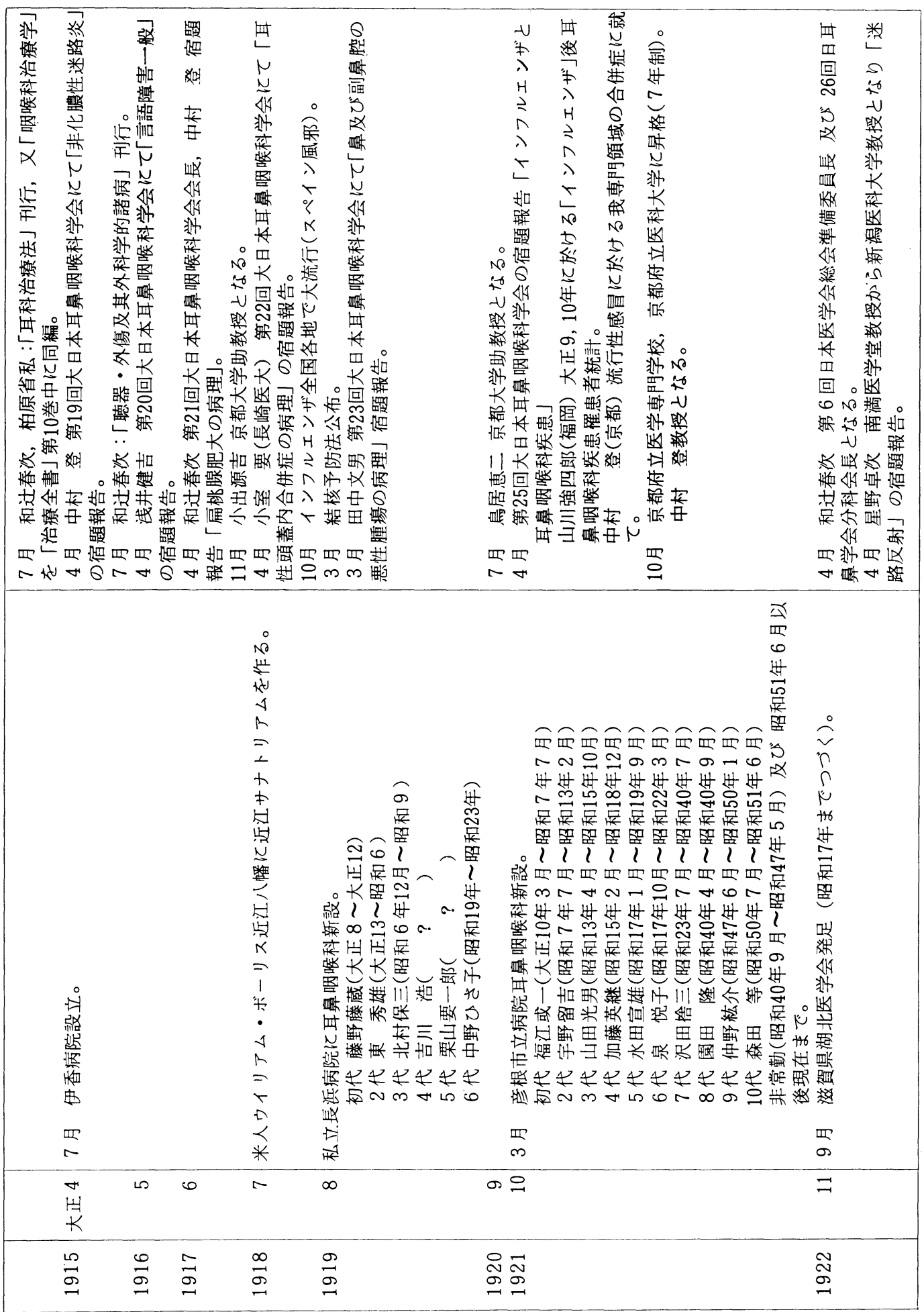




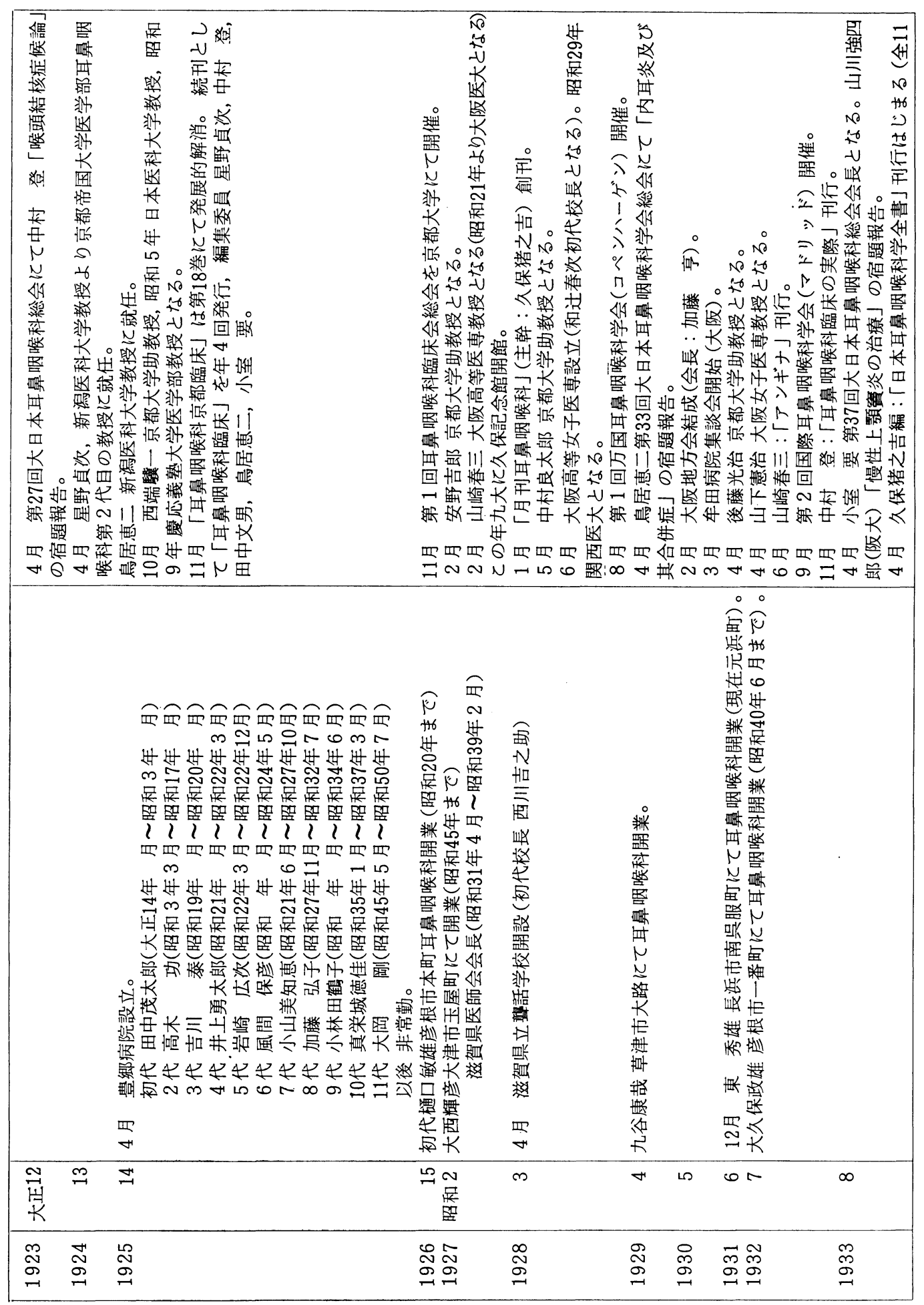




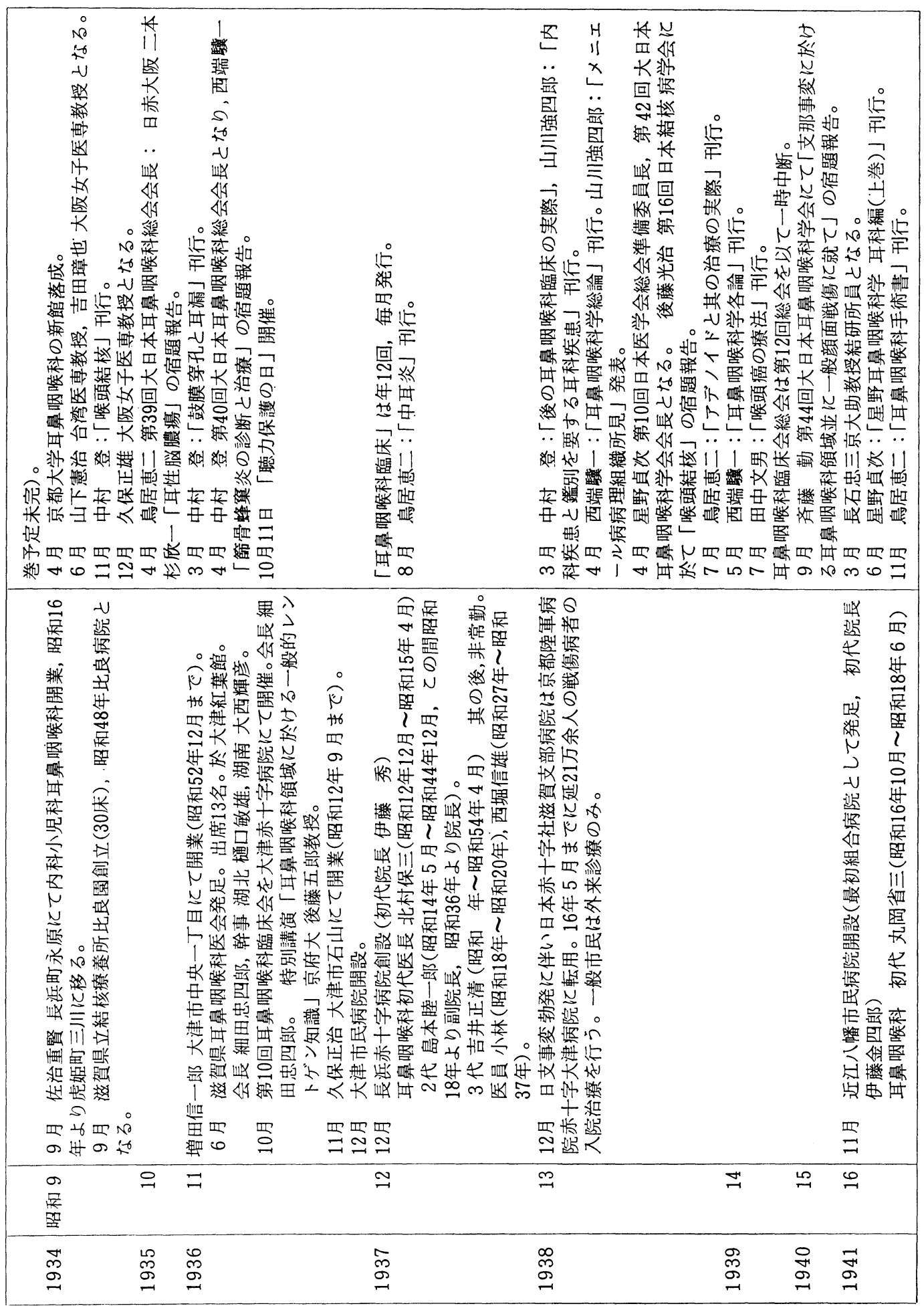




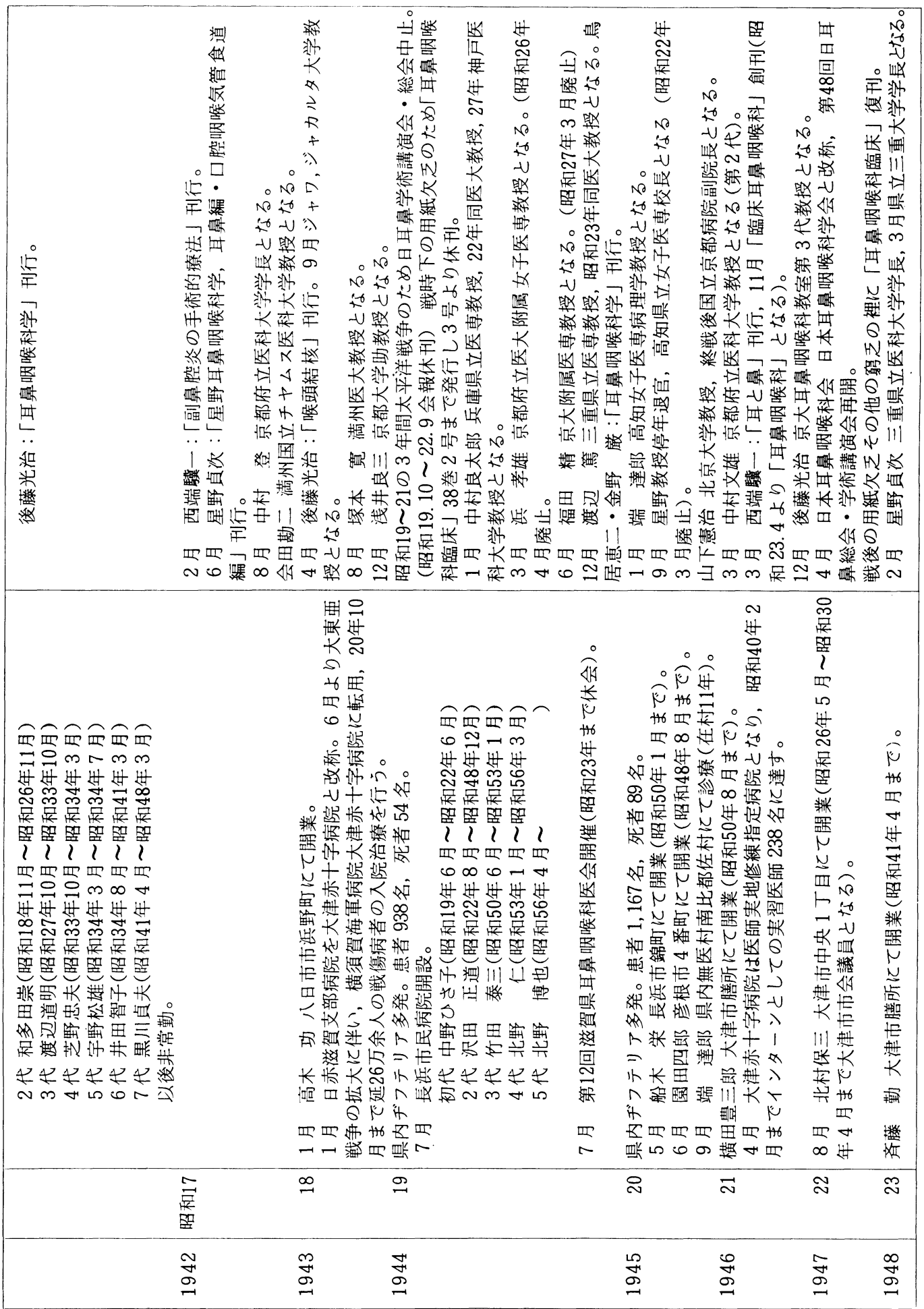




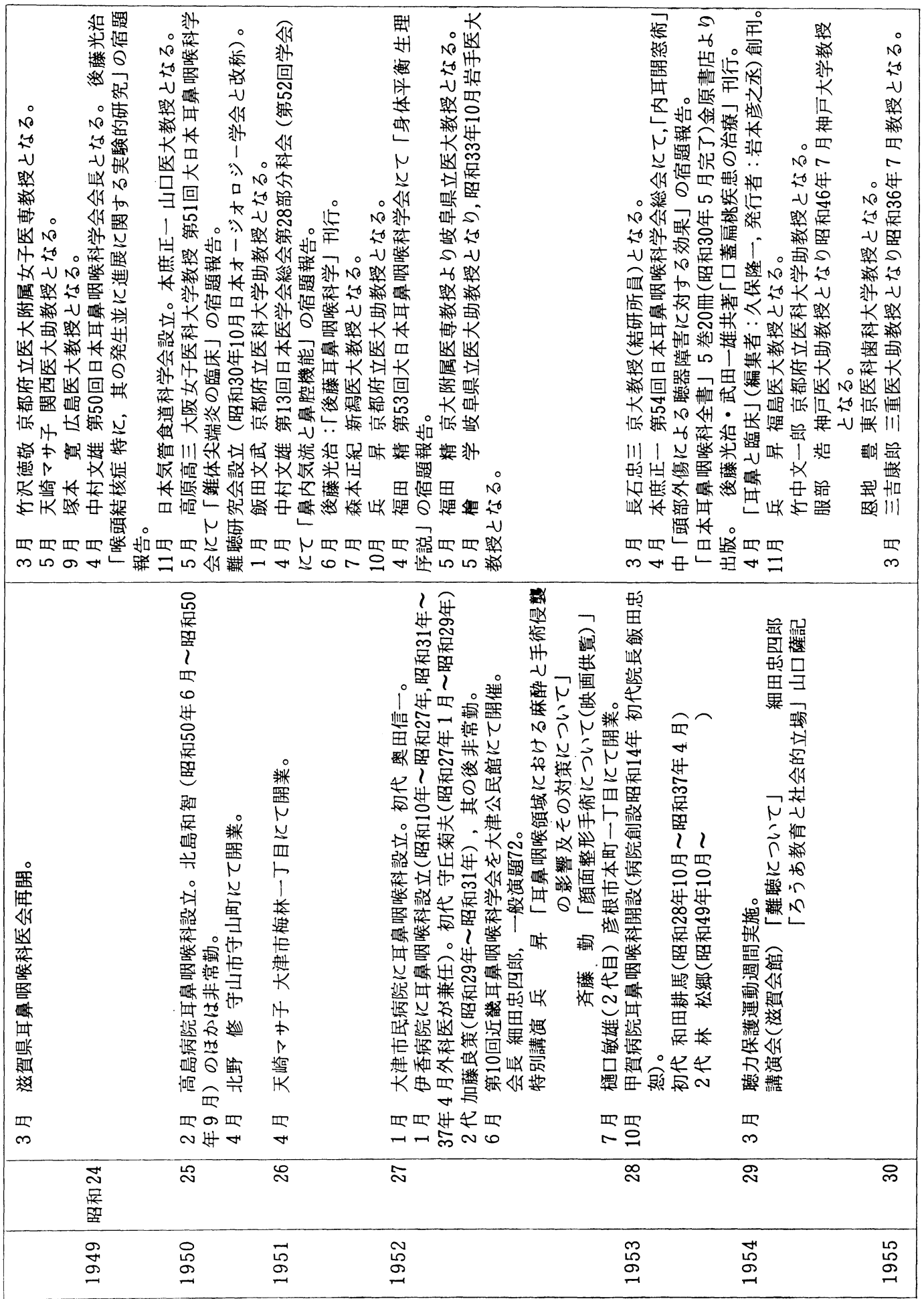




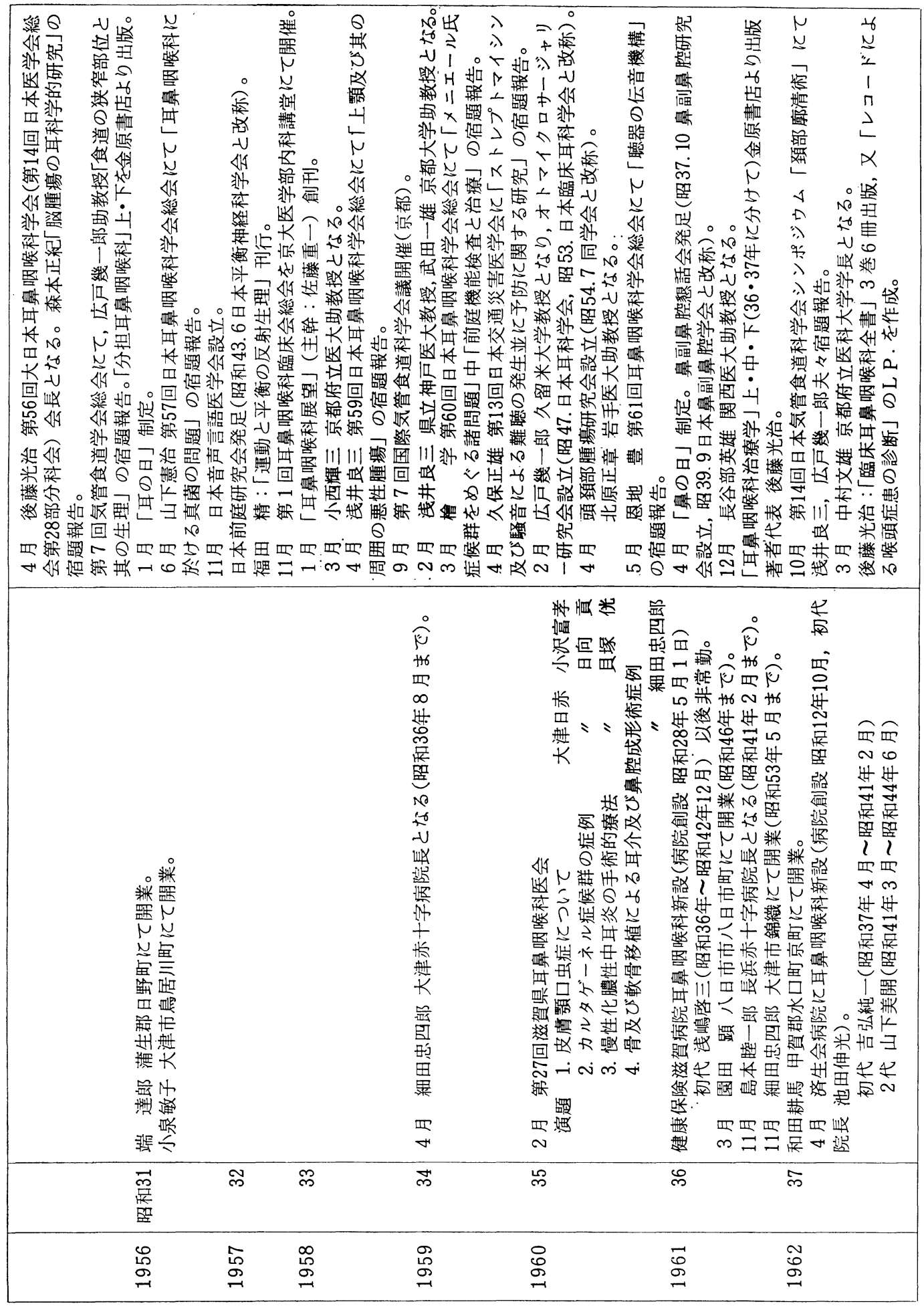




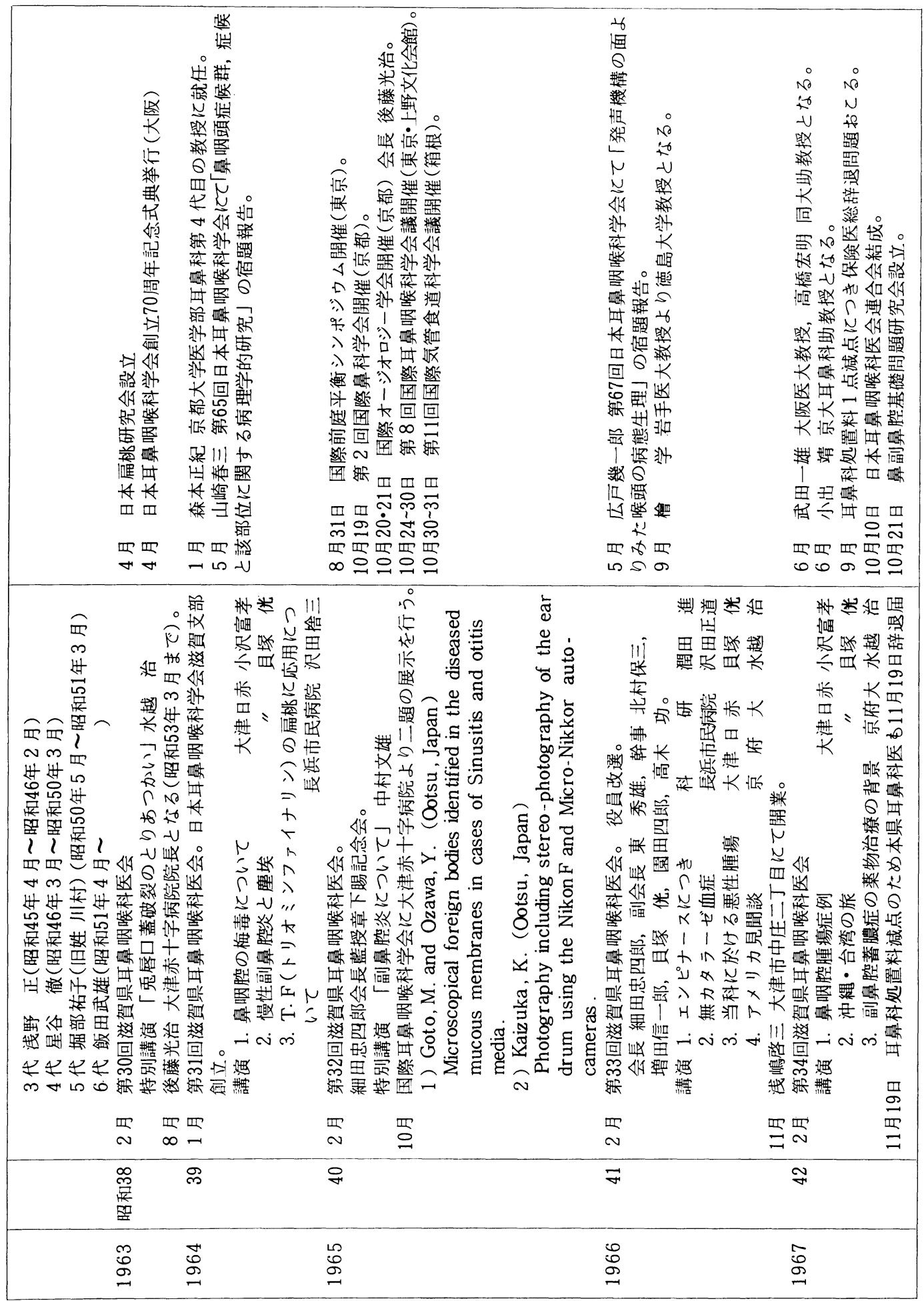




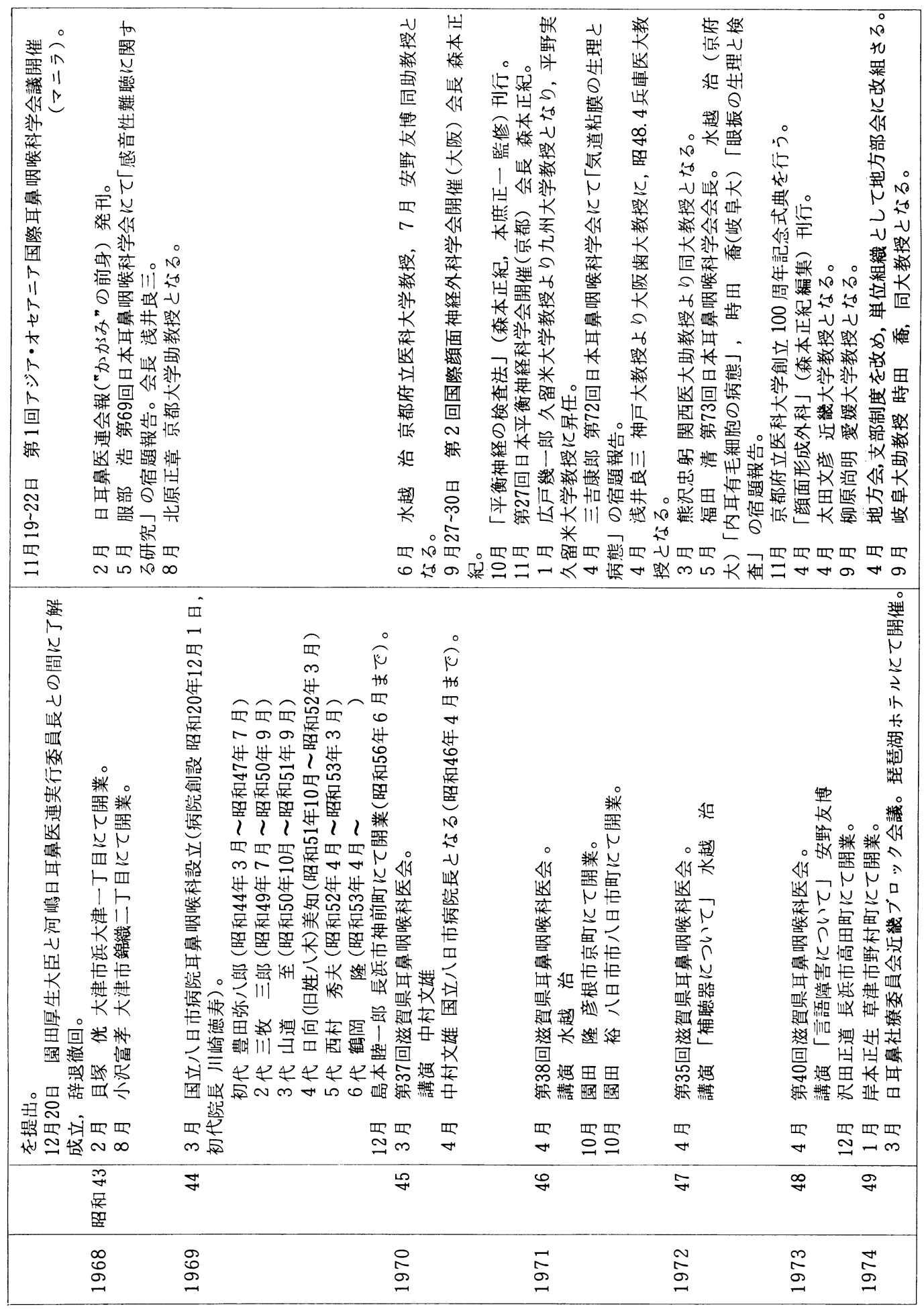




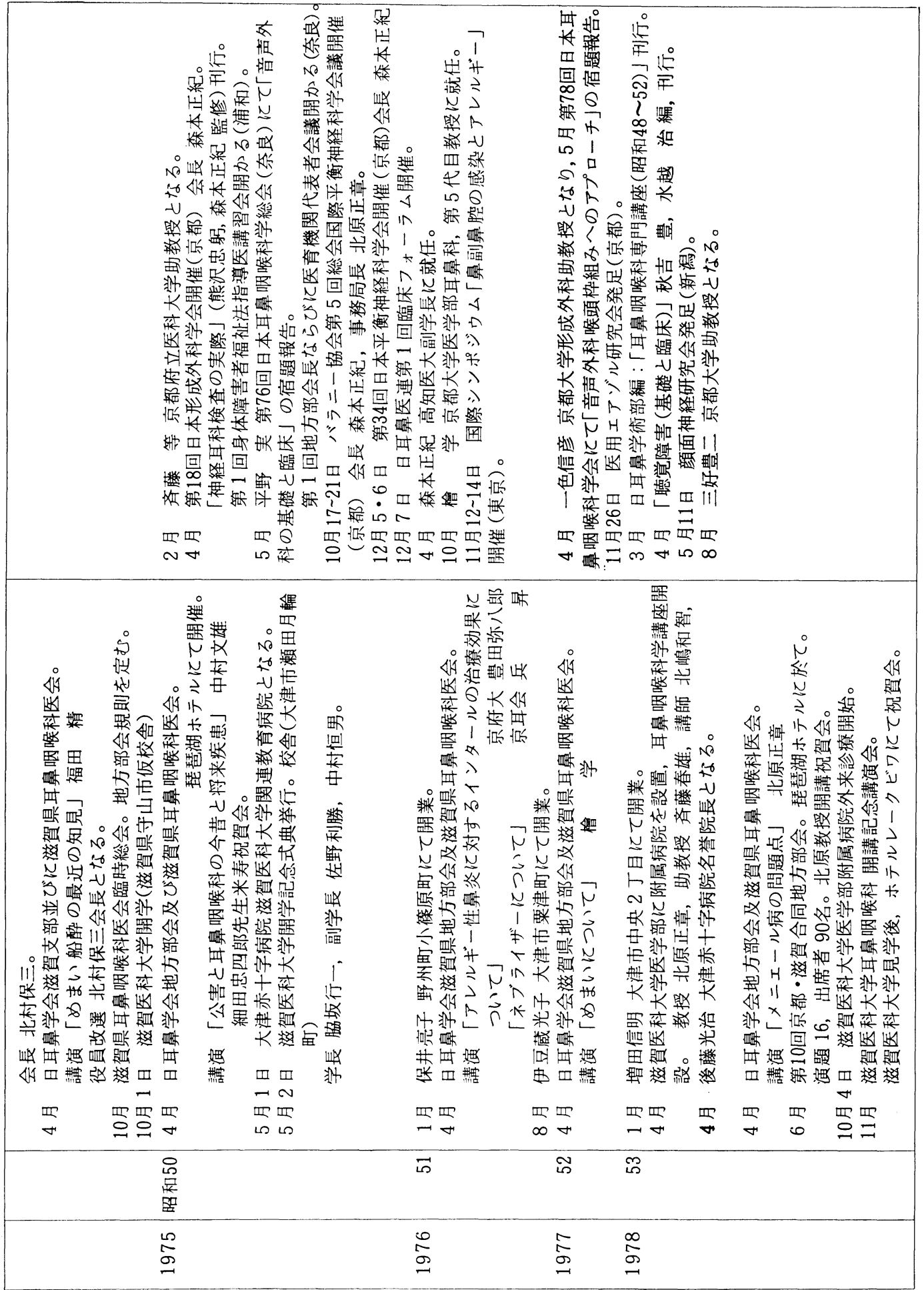




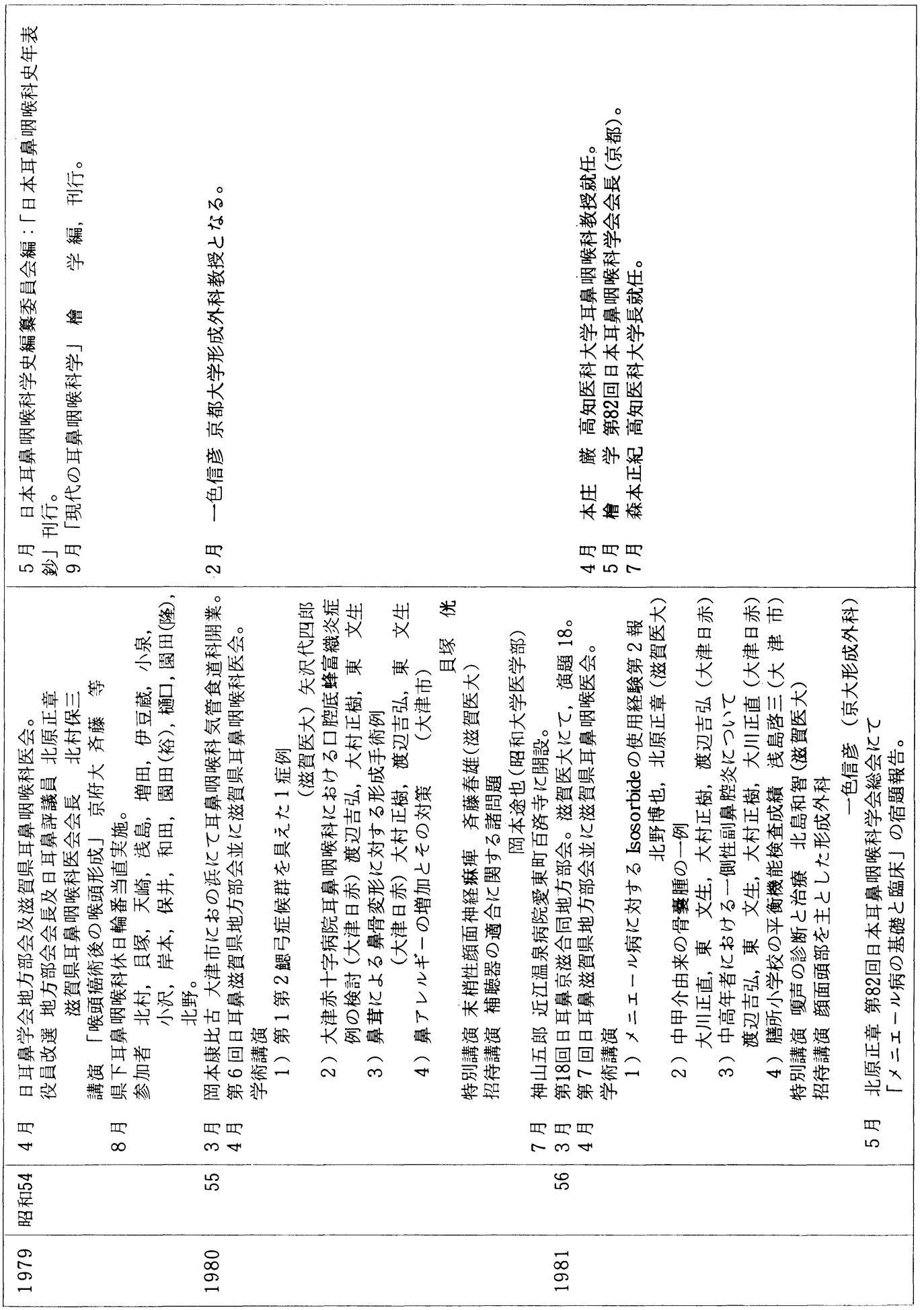

